\title{
Little Ice Age climate and oceanic conditions of the Ross Sea, Antarctica from a coastal ice core record
}

\author{
R. H. Rhodes ${ }^{1,2, *}$, N. A. N. Bertler ${ }^{1,2}$, J. A. Baker ${ }^{3}$, H. C. Steen-Larsen ${ }^{4}$, S. B. Sneed ${ }^{5}$, U. Morgenstern ${ }^{2}$, and \\ S. J. Johnsen ${ }^{4}$ \\ ${ }^{1}$ Antarctic Research Centre, Victoria University of Wellington, P.O. Box 600, Wellington, 6140, New Zealand \\ ${ }^{2}$ GNS Science, National Ice Core Research Laboratory, P.O. Box 30-368, Lower Hutt, 5040, New Zealand \\ ${ }^{3}$ School of Geography, Environment and Earth Sciences, Victoria University of Wellington, P.O. Box 600, \\ Wellington, New Zealand \\ ${ }^{4}$ Centre for Ice and Climate, Niels Bohr Institute, Juliane Maries Vej 30, 2100 Copenhagen, Denmark \\ ${ }^{5}$ Climate Change Institute, University of Maine, Orono, ME 04469, USA \\ * present address: College of Earth, Ocean and Atmospheric Sciences, Oregon State University, Corvallis, OR 97331, USA
}

Correspondence to: R. H. Rhodes (rachael.rhodes@geo.oregonstate.edu)

Received: 29 November 2011 - Published in Clim. Past Discuss.: 10 January 2012

Revised: 30 June 2012 - Accepted: 2 July 2012 - Published: 30 July 2012

\begin{abstract}
Increasing paleoclimatic evidence suggests that the Little Ice Age (LIA) was a global climate change event. Understanding the forcings and associated climate system feedbacks of the LIA is made difficult by the scarcity of Southern Hemisphere paleoclimate records. We use a new glaciochemical record of a coastal ice core from Mt. Erebus Saddle, Antarctica, to reconstruct atmospheric and oceanic conditions in the Ross Sea sector of Antarctica over the past five centuries. The LIA is identified in stable isotope $(\delta \mathrm{D})$ and lithophile element records, which respectively demonstrate that the region experienced $1.6 \pm 1.4{ }^{\circ} \mathrm{C}$ cooler average temperatures prior to $1850 \mathrm{AD}$ than during the last $150 \mathrm{yr}$ and strong $\left(>57 \mathrm{~m} \mathrm{~s}^{-1}\right.$ ) prevailing katabatic winds between 1500 and $1800 \mathrm{AD}$. Al and Ti concentration increases of an order of magnitude ( $>120 \mathrm{ppb} \mathrm{Al}$ ) are linked to enhanced aeolian transport of complex silicate minerals and represent the strongest katabatic wind events of the LIA. These events are associated with three 12-30 yr intervals of cooler temperatures at ca. $1690 \mathrm{AD}, 1770 \mathrm{AD}$ and $1840 \mathrm{AD}$. Furthermore, ice core concentrations of the biogenic sulphur species $\mathrm{MS}^{-}$suggest that biological productivity in the Ross Sea polynya was $\sim 80 \%$ higher prior to $1875 \mathrm{AD}$ than at any subsequent time. We propose that cooler Antarctic temperatures promoted stronger katabatic winds across the Ross Ice Shelf, resulting in an enlarged Ross Sea polynya during the LIA.
\end{abstract}

\section{Introduction}

The Little Ice Age (LIA) is typically considered to be a Northern Hemisphere climate phenomenon characterised by alpine glacial advances and relatively cool temperatures observed between 15th to mid-19th centuries (Grove, 1988). However, the timing, magnitude and character of the LIA climate response all exhibit strong regional variations (Jones and Mann, 2004). The cause of the LIA has been considered widely, with explanations ranging from increased volcanism, reduced solar irradiance and ocean circulation changes (e.g. Ammann et al., 2007; Broecker, 2000; Crowley, 2000; Miller et al., 2012). Furthermore, paleoclimate records suggest that the LIA is the most recent cooling event of a series that punctuated the Holocene (Domack and Mayewski, 1999; Masson et al., 2000). This apparent oscillatory behaviour in Holocene climate has led to speculation about what role the thermohaline circulation of the world's oceans may have played in instigating or amplifying these climate changes (Broecker, 2000; Denton and Broecker, 2008). Currently, no consensus has been reached on this issue and a key concern is the spatial bias toward Northern Hemisphere proxy and meteorological records (Jones et al., 2009). An important tool to understand the LIA must therefore be the acquisition and interpretation of Southern Hemisphere paleoclimate records, but few are currently available (Jones and Mann, 2004). 


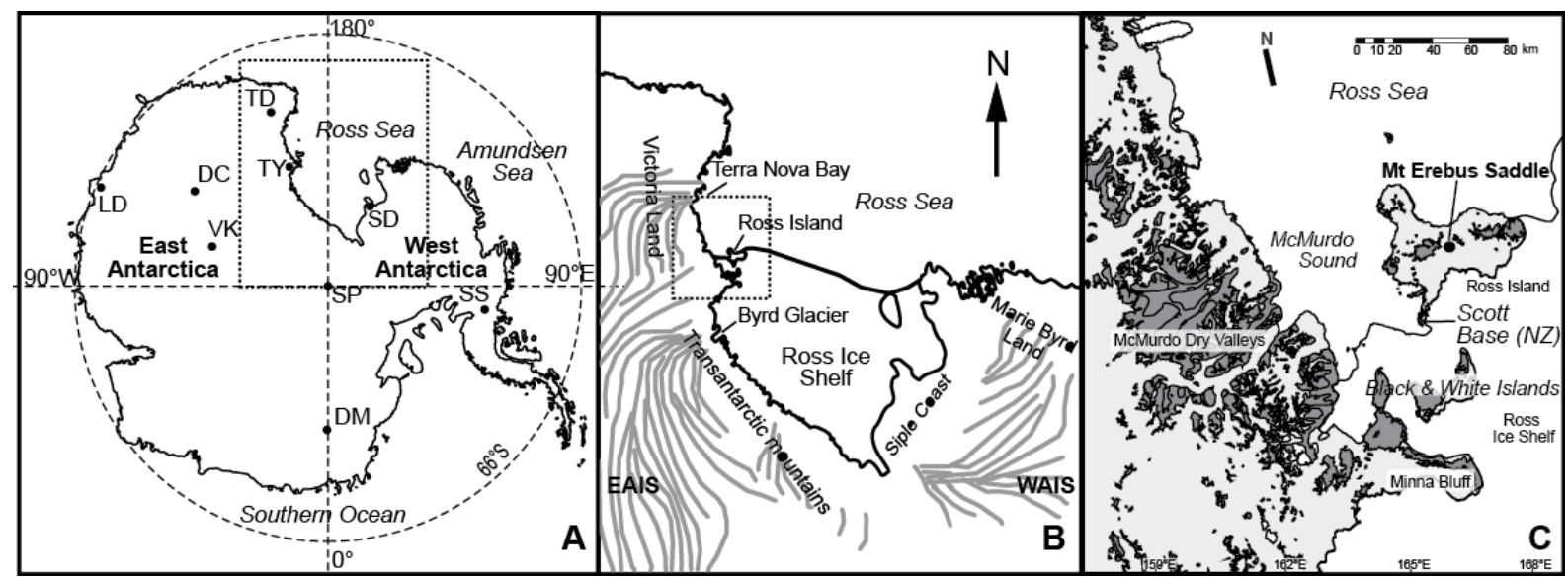

Fig. 1. (A) Map of the Antarctic continent. Locations of major ice core sites are marked by solid black circles and are labelled as follows: $\mathrm{DC}=$ EPICA Dome C; DM = EPICA Dronning Maud Land; LD = Law Dome; SD = Siple Dome; SP = South Pole; SS = Siple Station; $\mathrm{TD}=$ Talos Dome; TY = Taylor Dome. The dashed rectangle defines the area of map B. (B) Map of the Ross Sea region bound by the East Antarctic Ice Sheet (EAIS) and the West Antarctic Ice Sheet (WAIS). Approximate katabatic flow paths are indicated by grey arrows (modified after Parish, 1988). The dashed rectangle defines the area of map C. (C) Map of McMurdo Sound area. The location of Mt. Erebus Saddle (MES) is shown. Dark grey shading indicates areas of exposed rock outcrop.

Antarctic ice cores are valuable archives of past climate, and several ice cores have recently been obtained with sufficient temporal resolution to record the LIA. Whilst significant spatial and temporal variability exists (Masson et al., 2000; Morgan and van Ommen, 1997; Mosley-Thompson and Thompson, 1990; Stenni et al., 2002), records suggest that Antarctica experienced cooling synchronous with the Northern Hemisphere during the LIA (Bertler et al., 2011) an observation that is not consistent with a scenario involving oceanic thermohaline circulation reorganisation as the driver of climatic change (cf. Broecker, 2000; Denton and Broecker, 2008).

In this study, we examine the climate of the LIA in a key region of Antarctica using sub-annual resolution glaciochemical records from a coastal ice core from Mt. Erebus Saddle (MES), close to the edge of the Ross Ice Shelf in the southwestern Ross Sea sector (Fig. 1). The Ross Sea polynya, which is located along the edge of the Ross Ice Shelf, is a major site of Southern Ocean sea ice generation (Tamura et al., 2008), which drives bottom water formation (Jacobs and Giulivi, 1998). Additionally, the region is the most biologically productive area of the Southern Ocean (Arrigo and van Dijken, 2003). Consequently, climatic changes occurring here have the potential to produce feedbacks that influence both regional conditions and the global climate system (Mayewski et al., 2009). The MES ice core site is at a boundary between the influence of two contrasting meteorological regimes. Air masses originate from both the Southern Ocean, in the form of cyclones (Sinclair et al., 2010), and the interior of Antarctica, in the form of katabatic flow (Sinclair et al., 2010; Bromwich et al., 1992). The two dominant air masses have contrasting geochemical characteristics that allow them to be identified (Bertler et al., 2004b). Thus, the location of the MES ice core site allows the meteorological regimes of the interior of Antarctica and the Ross Sea region to be traced back through time in the same ice core record.

A continuous record of ice core lithophile element concentrations from this site spanning five centuries provides a proxy for katabatic wind speeds, which were stronger prior to $1850 \mathrm{AD}$ than at any ensuing time. Furthermore, by linking the katabatic wind proxy with methylsulphonate $\left(\mathrm{MS}^{-}\right)$, a tracer of marine primary productivity, we demonstrate that stronger katabatic winds caused a larger or more persistent Ross Sea polynya between 1600 and 1875 AD.

\section{Methodology}

\subsection{Study site}

MES is a local snow accumulation zone situated between Mt. Erebus and Mt. Terra Nova on Ross Island at an altitude of $1600 \mathrm{~m}$ (Fig. 1) $\left(77^{\circ} 30.90^{\prime} \mathrm{S}, 167^{\circ} 40.59^{\prime} \mathrm{E}\right)$. Ice flows from the saddle towards NNW and SSE directions. Ground penetrating radar reconnaissance indicated a depth to bedrock of $220 \mathrm{~m}$ and imaged parallel isochrones, suggesting favourable glaciological conditions for the preservation of a continuous, annually resolved ice core record. A 168m-deep ice core was drilled in the central zone of minimum ice flow in December 2006. Annual temperature at the site, ascertained from firn temperature logging, is $-25.6^{\circ} \mathrm{C}$. The depth-density profile generated from density measurements conducted in the field is well explained by the densification model of Herron and Langway (1980) using a critical density of $550 \mathrm{~kg} \mathrm{~m}^{-3}$ and an initial density of $370 \mathrm{~kg} \mathrm{~m}^{-3}$. The 
accumulation rate, calculated from the annual layer count, is $0.23 \mathrm{~m}$ water equivalent (w.e.) $\mathrm{yr}^{-1}$.

\subsection{Core processing}

Here we present data from the uppermost $120 \mathrm{~m}$ of the MES ice core. The core was processed at the New Zealand Ice Core Laboratory, GNS Science, using a continuous melter system which sampled discrete aliquots from the pristine interior of the core for chemical analysis (Osterberg et al., 2006). Stable isotope ratios $\left(\delta^{18} \mathrm{O}\right.$ and $\left.\delta \mathrm{D}\right)$ were determined on samples from corresponding depths obtained from the outer section of core. The mean sampling resolution was 43 samples $\mathrm{m}^{-1}$ between 0 and $66 \mathrm{~m}$ depth and 61 samples $\mathrm{m}^{-1}$ between $66 \mathrm{~m}$ and $120 \mathrm{~m}$ depth. Inductively coupled plasma mass spectrometry (ICP-MS) sample resolution was reduced to 30.5 samples $\mathrm{m}^{-1}$ between $77 \mathrm{~m}$ and $120 \mathrm{~m}$ to improve the efficiency of processing.

All vials used to sample material intended for ion chromatography (IC) or ICP-MS analysis were rigorously cleaned to prevent chemical contamination. The polypropylene vials used for IC samples were triple-rinsed with ultrapure water $(>18.2 \mathrm{M} \Omega$ ), soaked for three days and triplerinsed again. The polypropylene vials used for ICP-MS samples were first triple-rinsed with ultra-pure water then soaked in $5 \mathrm{wt} . \% \mathrm{HNO}_{3}$ for a minimum of 10 days, triple-rinsed, soaked in ultra-pure water for a minimum of 3 days and triple-rinsed with ultra-pure water.

Procedural blanks were used to monitor the potential contribution of the processing and sampling procedures to the measured concentrations of chemical species measured. The chemical concentrations recorded in the procedural blanks (Table S1 in the Supplement) are negligible compared to the variability in concentration exhibited in the ice core record for all chemical species except $\mathrm{Zr}$ and $\mathrm{Ca}$ (Supplement).

\subsection{Analytical methods}

\subsubsection{Stable isotope ratios}

The stable isotope ratios $\delta^{18} \mathrm{O}$ and $\delta \mathrm{D}$ (where $\delta^{18} \mathrm{O}=$ $\left(\left(\left[\left({ }^{18} \mathrm{O} /{ }^{16} \mathrm{O}\right)_{\text {sample }} /\left({ }^{18} \mathrm{O} /{ }^{16} \mathrm{O}\right)_{\mathrm{V} \text {-SMOW }}\right]-1\right) \times 1000\right)$ and $\delta \mathrm{D}$ $\left.=\left(\left(\left[\left({ }^{2} \mathrm{H} /{ }^{1} \mathrm{H}\right)_{\text {sample }} /\left({ }^{2} \mathrm{H} /{ }^{1} \mathrm{H}\right)_{\mathrm{V} \text {-SMOW }}\right]-1\right) \times 1000\right)\right)$ were measured at the Stable Isotope Laboratory, GNS Science. Samples from the upper $91 \mathrm{~m}$ of the ice core were analysed with a GVI Isoprime mass spectrometer by methods reported previously (Bertler et al., 2011). The analytical precision on this instrument was $\pm 0.1 \%$ for $\delta^{18} \mathrm{O}$ and $\pm 1.0 \%$ for $\delta \mathrm{D}$, resulting in an uncertainty of $\pm 1.3 \%$ on the second order parameter deuterium excess $\left(\mathrm{d}\right.$-excess $\left.=\delta \mathrm{D}-8 \times \delta^{18} \mathrm{O}\right)$, Dansgaard, 1964).

Samples from $92 \mathrm{~m}$ to $120 \mathrm{~m}$ depth were analysed using a Los Gatos Research Liquid Water Isotope Analyser, which simultaneously measures $\delta^{18} \mathrm{O}$ and $\delta \mathrm{D}$ by laser absorption spectroscopy. $\delta^{18} \mathrm{O}$ and $\delta \mathrm{D}$ were calibrated using internal standards: MM1 with reported values of $-29.4 \%$ for $\delta^{18} \mathrm{O}$ and $-231.51 \%$ for $\delta \mathrm{D}$, and INS11 with reported values of $-0.4 \%$ for $\delta^{18} \mathrm{O}$ and $-4.6 \%$ for $\delta \mathrm{D}$, and reported with respect to V-SMOW. Isotopic standard INS9 $(-17.4 \%$ for $\delta^{18} \mathrm{O}$ and, $-131.0 \%$ ofor $\left.\delta \mathrm{D}\right)$ was analysed to check the accuracy of the calibration. Each sample is analysed six times in succession, enabling memory effects from previous samples to be identified and removed. The analytical precision on this instrument was $\pm 0.2 \%$ for $\delta^{18} \mathrm{O}$ and $\pm 0.6 \%$ for $\delta \mathrm{D}$, resulting in an uncertainty of $\pm 1.7 \%$ on d-excess.

Comparison of stable isotope ratios of a batch of samples measured by mass spectrometry and by laser spectroscopy identified a systematic offset between the values determined by the two techniques. The stable isotope ratios of MES ice core samples measured by laser spectroscopy were therefore corrected for this offset. Details of this correction are provided in the Supplement. A revised analytical uncertainty for d-excess, which takes into account the errors on both instruments, is calculated as $\pm 2.1 \%$.

\subsubsection{Ion chromatographic analysis of major ions}

Ion chromatographic analysis of major ions $\left(\mathrm{Na}^{+}, \mathrm{Mg}^{2+}\right.$, $\mathrm{Ca}^{2+}, \mathrm{MS}^{-}, \mathrm{Cl}^{-}, \mathrm{NO}_{3}^{-}, \mathrm{SO}_{4}^{2-}$ ) was conducted at the Climate Change Institute, University of Maine. Anions were measured using a Dionex AS- 18 column, $400 \mu$ sample loop with a $\mathrm{KOH}$ eluent concentration of $35 \mathrm{mM}$. Cations were measured using a Dionex CS-12A column and a $500 \mu$ loop with $25 \mathrm{mM}$ methanesulphonic acid eluent. Calibration using five standards bracketing the anticipated concentration range routinely achieved correlation coefficients of $R^{2}>0.99$ for all analytes. An external reference material ION-92 (Environment Canada) was analysed at dilutions of 100 and 1000 times to verify the calibration. $\mathrm{Na}^{+}, \mathrm{Mg}^{2+}, \mathrm{Ca}^{2+}$, $\mathrm{MS}^{-}, \mathrm{Cl}^{-}$, and $\mathrm{SO}_{4}^{2-}$ measurements are accurate to within $5 \%$. The reproducibilities $(2 \times$ relative standard deviation, RSD) of $\mathrm{Na}^{+}, \mathrm{Mg}^{2+}, \mathrm{Ca}^{2+}$ and $\mathrm{MS}^{-}$measurements are $<11 \%$ and $<4 \%$ for $\mathrm{Cl}^{-}$, and $\mathrm{SO}_{4}^{2-}$. $\mathrm{NO}_{3}^{-}$, is not detectable in ION-92.

\subsubsection{Inductively coupled plasma mass spectrometric analysis of trace elements}

Ice core samples were analysed for concentrations of major, minor and trace elements (Na, Mg, Al, Ca, Ti, V, Mn, As, Rb, $\mathrm{Sr}, \mathrm{Y}, \mathrm{Zr}, \mathrm{Cs}, \mathrm{Ba}, \mathrm{La}, \mathrm{Ce}, \mathrm{Pr}, \mathrm{Tl}, \mathrm{Pb}, \mathrm{Bi}$, Th, U) by ICP-MS (Agilent 7500cs Series) in the Geochemistry Laboratory of the School of Geography, Environment and Earth Sciences, Victoria University of Wellington. The operating conditions adopted for ICP-MS analysis are provided in Table S2 in the Supplement.

Calibration standards were gravimetrically diluted daily from stock mixed element standards made up from mono-elemental $1000 \mathrm{ppm}$ standards. Element concentrations in these standards varied according to the relative 
Table 1. Element concentrations (ppt, except where indicated) determined by repeated measurement of SLRS-4 riverine water standard $(n=82)$ with the precision and accuracy of measurements.

\begin{tabular}{lllrr}
\hline Element & This study & $\begin{array}{l}\text { Certified } \\
\text { values }\end{array}$ & $\begin{array}{r}\text { Precision } \\
2 \times \mathrm{RSD}^{\mathrm{b}}(\%)\end{array}$ & $\begin{array}{r}\text { Accuracy } \\
(\% \text { difference })\end{array}$ \\
\hline $\mathrm{Na}^{\mathrm{a}}$ & $2289 \pm 80$ & $2400 \pm 200$ & 3.5 & 4.6 \\
$\mathrm{Mg}^{\mathrm{a}}$ & $1573 \pm 156$ & $1600 \pm 100$ & 9.9 & 1.7 \\
$\mathrm{Al}^{\mathrm{a}}$ & $56 \pm 4$ & $54 \pm 4$ & 6.8 & 4.0 \\
$\mathrm{Ca}^{\mathrm{a}}$ & $6132 \pm 546$ & $6200 \pm 200$ & 8.9 & 1.1 \\
$\mathrm{Mn}^{\mathrm{a}}$ & $3.56 \pm 0.14$ & $3.37 \pm 0.18$ & 4.0 & 5.5 \\
$\mathrm{Ba}$ & $13.0 \pm 0.44$ & $12.22 \pm 0.6$ & 3.4 & 6.4 \\
$\mathrm{Ti}$ & $1587 \pm 152$ & $1460 \pm 80$ & 9.6 & 8.7 \\
$\mathrm{~V}$ & $382 \pm 19$ & $320 \pm 30$ & 5.1 & 19.3 \\
$\mathrm{As}$ & $757 \pm 21$ & $680 \pm 60$ & 2.7 & 11.3 \\
$\mathrm{Rb}$ & $1616 \pm 59$ & $1530 \pm 50$ & 3.7 & 5.6 \\
$\mathrm{Sr}$ & $29783 \pm 1269$ & $26300 \pm 3200$ & 4.3 & 13.2 \\
$\mathrm{Y}$ & $143 \pm 6$ & $146 \pm 8$ & 4.0 & 2.0 \\
$\mathrm{Zr}$ & $139 \pm 45$ & $120 \pm 15$ & 32.2 & 15.9 \\
$\mathrm{Cs}$ & $6.80 \pm 0.23$ & $9 \pm 1$ & 3.4 & 24.5 \\
$\mathrm{La}$ & $298 \pm 15$ & $287 \pm 8$ & 5.1 & 3.9 \\
$\mathrm{Ce}$ & $375 \pm 27$ & $360 \pm 12$ & 7.3 & 4.1 \\
$\mathrm{Pr}$ & $83.4 \pm 10.6$ & $69.3 \pm 1.8$ & 12.6 & 20.4 \\
$\mathrm{Tl}$ & $7.96 \pm 2.31$ & $6.8 \pm 1.3$ & 29.0 & 17.0 \\
$\mathrm{~Pb}$ & $82.0 \pm 5.7$ & $86 \pm 7$ & 6.9 & 4.7 \\
$\mathrm{Bi}$ & $2.40 \pm 0.34$ & $2.1 \pm 0.1$ & 14.0 & 14.4 \\
$\mathrm{Th}$ & $21.5 \pm 1.9$ & $18 \pm 3$ & 9.1 & 19.6 \\
$\mathrm{U}$ & $51.1 \pm 4.9$ & $50 \pm 3$ & 9.6 & 2.3 \\
\hline $\mathrm{Co}$ & & & &
\end{tabular}

${ }^{\mathrm{a}}$ Concentrations in parts per billion (ppb); ${ }^{\mathrm{b}} \mathrm{RSD}=$ relative standard deviation.

Certified values for SLRS-4 are GeoReM (Jochum et al., 2005) preferred values obtained from http://georem.mpch-mainz.gwdg.de.

concentrations expected in the ice core samples. Additional tuning was required to calibrate measurements conducted by the two different detector types (pulse and analog) on elements which recorded $>1000000$ counts $^{-1}$ (Na, Mg and $\mathrm{Al})$.

Samples were stored frozen prior to analysis, then thawed, and acidified to 1 wt. $\% \mathrm{HNO}_{3}$ with $68 \mathrm{wt} . \% \mathrm{HNO}_{3}$ (Seastar) at least $12 \mathrm{~h}$ prior to analysis. Counts recorded on 1 wt. $\% \mathrm{HNO}_{3}$ blanks were subtracted from those recorded on samples and standards to correct for background contributions. Detection limits are calculated as $3 \sigma$ on the blank measurements (Table S1 in the Supplement). The calibration standards were run as bracketing standards every 12 samples to correct for instrumental drift. An external reference material, SLRS-4 (National Research Council, Canada), was run at 10 times dilution during each analytical session to test the accuracy and reproducibility of the measurements (Table 1).

\subsubsection{Tritium analysis}

Six ice core samples from a depth range of $11 \mathrm{~m}$ to $21.3 \mathrm{~m}$ were measured directly without prior tritium enrichment by ultra-low-level liquid scintillation spectrometry (Quantulus ${ }^{\mathrm{TM}}$ ) in a monitored tritium-free environment. The water samples were purified in a vacuum distillation system to exclude tritium contamination. Details of the tritium analysis procedure are described in Morgenstern and Taylor (2009).

\section{Dating}

\subsection{Annual layer counting}

A snow pit sampled at MES two years prior to drilling of the ice core was dated by identification of annual peaks in $\delta^{18} \mathrm{O}$ for the time period 2000 to $2005 \mathrm{AD}$ (Rhodes et al., 2009). The equivalent section of the $\delta^{18} \mathrm{O}$ record was located in the ice core to facilitate dating of the uppermost section. Maximum values in the annual signals of $\delta^{18} \mathrm{O}$ and $\delta \mathrm{D}$ in the top $25 \mathrm{~m}$ of the ice core were identified as mid-summer (1 January) (Fig. 4). The annual cycles in $\delta^{18} \mathrm{O}$ and $\delta \mathrm{D}$ often appear asymmetric in form (i.e. not perfectly sinusoidal) as a result of a seasonal bias in accumulation events (Cuffey and Steig, 1998) and/or winter snow ablation at the MES site. Harsh weather conditions at this site prevented deployment of a weather station to monitor precipitation and ablation events. $\mathrm{NO}_{3}^{-}$displayed a well-defined annual signal with maximum values in winter-spring, possibly as the result of production in stratospheric clouds (Michalski et al., 2005). 
Molecular diffusion in the firn pore space resulted in significant smoothing of the annual $\delta^{18} \mathrm{O}$ and $\delta \mathrm{D}$ cycles deeper down the core (Johnsen, 1977; Johnsen et al., 2000). The $\delta^{18} \mathrm{O}$ and $\delta \mathrm{D}$ time series were therefore deconvolved/back-diffused to obtain the original high frequency signal (Johnsen, 1977; Johnsen et al., 2000) (Fig. S4 in the Supplement). The back-diffused time series were used to count annual layers in the ice core to $61.1 \mathrm{~m}$ depth (1816 AD).

\subsection{Age tie points}

In order to verify the interpretation of $\delta \mathrm{D}$ peaks as annual layers in the MES core, six samples were analysed for tritium $\left({ }^{3} \mathrm{H}\right)$ content. Elevated tritium contents related to thermonuclear bomb testing were determined in the MES ice core between 1964 and $1972 \mathrm{AD}$, in line with tritium contents measured in snow pits on the Ross Ice Shelf and at Halley Bay, Antarctic Peninsula, and in New Zealand precipitation (Fig. 2). MES tritium contents are lower than those of the other Antarctic locations plotted but are similar to those measured on Law Dome material (unpublished data, not shown). This may be the result of the strong marine cyclonic influence at both MES (Sinclair et al., 2010) and Law Dome (McMorrow et al., 2002), which dilutes the stratospheric tritium signal. These tritium measurements confirmed the validity of our approach to annual layer counting in the absence of accumulation data. The depth-age model was not adjusted to fit to this age tie point.

Positive identification of volcanic nss (non-sea salt) $\mathrm{SO}_{4}^{2-}$ deposition in the MES ice core for dating purposes (e.g. Traufetter et al., 2004) is challenging, because the $\mathrm{nssSO}_{4}^{2-}$ signal is dominated by biogenic $\mathrm{nssSO}_{4}^{2-}$ from the seasonally open ocean. As an alternative, we examined the deposition history of heavy, volatile trace elements, which are emitted by volcanoes (Hinkley et al., 1994) and may be deposited on ice sheets (Kaspari et al., 2007; Kellerhals et al., 2010). In the MES ice core, $\mathrm{Pb}, \mathrm{Bi}$ and $\mathrm{Tl}$ are all strongly enriched relative to terrestrial element concentrations in at least 8 consecutive samples between $60.5 \mathrm{~m}$ and $61.1 \mathrm{~m}$ depth (Fig. 3a). The initial annual layer count dated this signal to the year $1824 \mathrm{AD}$, within $8 \mathrm{yr}$ of the Mt. Tambora (Indonesia) eruption signal across Antarctica (Traufetter et al., 2004). However, Vallelonga et al. (2003) attributed elevated $\mathrm{Pb}$ and Bi concentrations in a Law Dome ice core (Fig. 1a) at this time to emissions from Mt. Erebus, on the basis of $\mathrm{Pb}$ isotopic signatures. As MES is located adjacent to Mt. Erebus, it is plausible that the trace element record of the MES ice core may record the eruption history of Mt. Erebus rather than that of global-scale stratospheric eruptions. In order to test this hypothesis, trace element ratios measured across the $\mathrm{Pb}$, $\mathrm{Tl}$ and $\mathrm{Bi}$ peaks were compared to trace element ratios measured in the plume of Mt. Erebus (Fig. 3b). None of the trace element ratios exhibit any marked deviation from the median value of the ice core record (green line) during the proposed

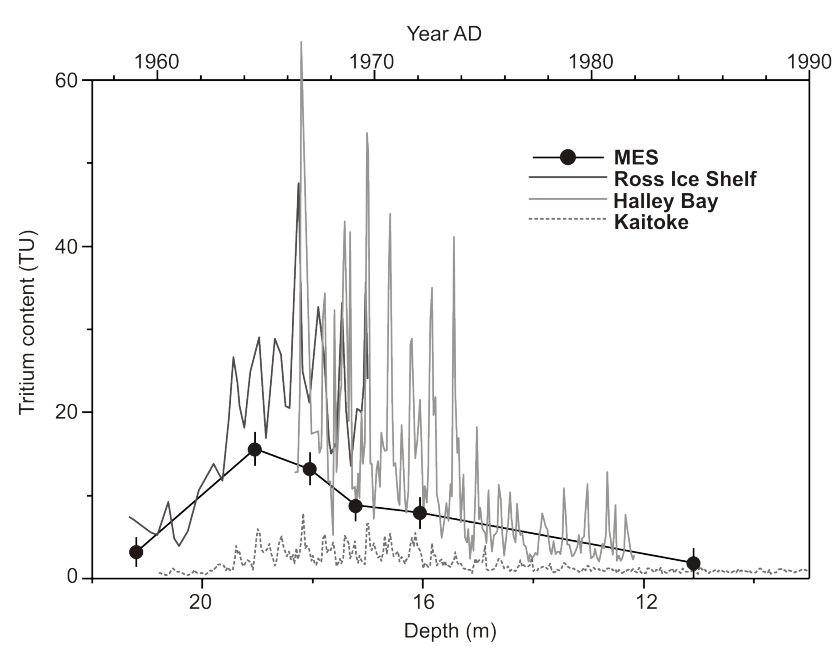

Fig. 2. Tritium contents of six MES ice core samples plotted with tritium contents of precipitation from the Ross Ice Shelf, Halley Bay, Antarctic Peninsula, and Kaitoke, New Zealand, decaycorrected to December 2006. Error bars are $1 \sigma$. The detection limit for analysis without prior enrichment is $2.5 \mathrm{TU}$. One tritium unit (TU) is defined as one atom of tritium per $10^{18}$ atoms of hydrogen, equivalent to 0.118 becquerels $(\mathrm{Bq})$ per litre of water.

Mt. Tambora eruption. This lends support to attribution of the $\mathrm{Bi}, \mathrm{Pb}$ and $\mathrm{Tl}$ peaks at $61.1 \mathrm{~m}$ to the Mt. Tambora eruption. Moreover, the median values (Fig. 3b, green line) of the trace element ratios across the MES ice core record differ from those of the Mt. Erebus plume (Fig. 3b, purple line), providing evidence that the ice core trace element budget is predominantly influenced by input from other sources.

\subsection{Ice flow model and dating uncertainty}

The 1-D flow model of Dansgaard and Johnsen (1969), tuned to the Mt. Tambora age tie point (1816 AD, $61.1 \mathrm{~m})$, was used to predict the depth-age relationship below this depth (Fig. S5 in the Supplement) and gives an age of 1473 AD at $120 \mathrm{~m}$ depth. The outcome of this model is sensitive to the prescribed accumulation rate. We employ an accumulation rate of $0.23 \mathrm{mw}$.e. $\mathrm{yr}^{-1}$, which is the mean 1950 to $2006 \mathrm{AD}$ value calculated from the annual layer count. This value is therefore subject to a potential error in the annual layer count. For this reason, the ice flow model was also run with accumulation rates of 0.21 and $0.25 \mathrm{~m}$ w.e. $\mathrm{yr}^{-1}$, which are equivalent to $\pm 5 \mathrm{yr}$ errors in the annual layer count back to $1950 \mathrm{AD}$. These runs produced age differences at $120 \mathrm{~m}$ of -84 and $+178 \mathrm{yr}$ respectively, as compared to the age predicted using a $0.23 \mathrm{mw}$ w.e. $\mathrm{yr}^{-1}$ accumulation rate (Fig. S5 in the Supplement). However, we have confidence in the mean accumulation rate of $0.23 \mathrm{~m}$ w.e. $\mathrm{yr}^{-1}$ and its stability over time for two reasons: (1) when the model is tuned to the Tambora age tie, the location of the bomb tritium peak (defined as $19.1 \mathrm{~m}$ depth $=1964.2 \mathrm{yr}$ ) is matched to within $0.5 \mathrm{yr}$, whilst using either of the other accumulation rates 


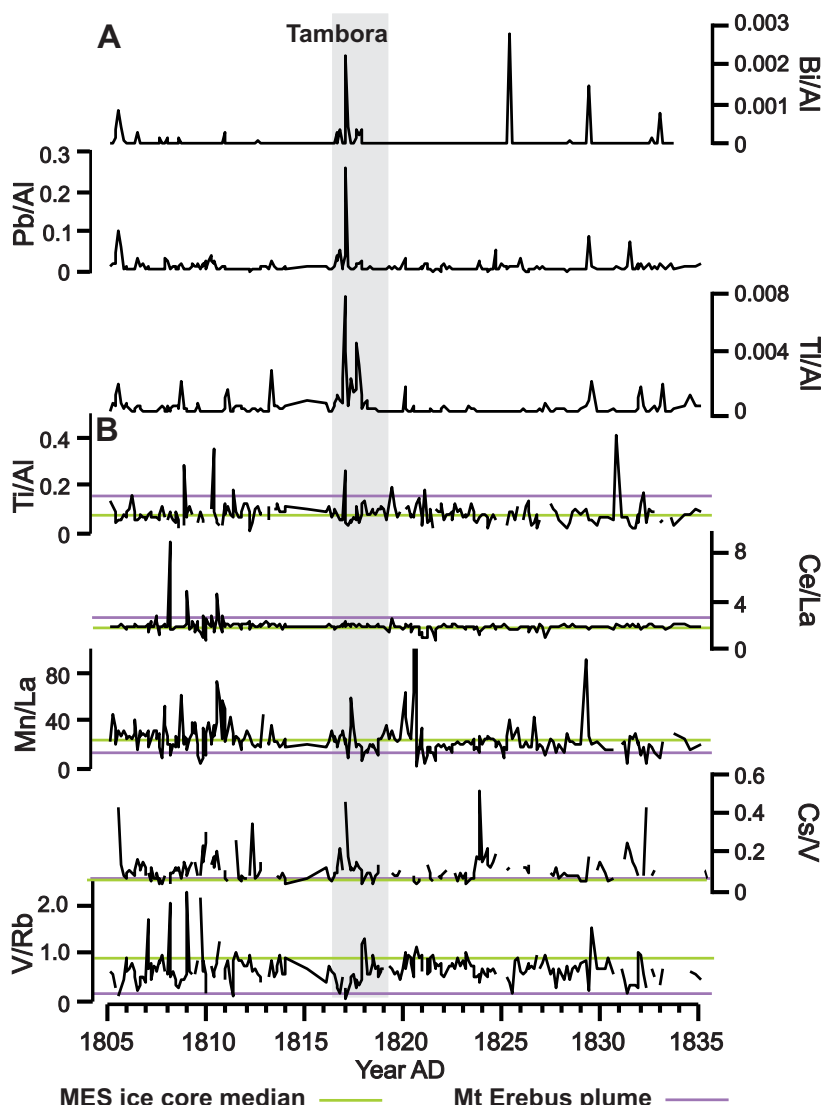

Fig. 3. (A) $\mathrm{Bi}, \mathrm{Pb}$ and $\mathrm{Tl}$ concentrations normalised to $\mathrm{Al}$ (a terrestrial element) across the Mt. Tambora eruption marker (grey shading). (B) Trace element ratio records from the MES core for the same time period, plotted with values for the Mt. Erebus plume (purple line) (Zreda-Gostynska et al., 1997) and the median values of the entire MES ice core record (green line). Breaks in the record occur where the concentration of an element is below the ICP-MS detection limit. Information on $\mathrm{Bi}, \mathrm{Pb}$ and $\mathrm{Tl}$ content of the Mt. Erebus plume is not available.

causes the bomb tritium peak location to be off by $>2 \mathrm{yr}$; (2) if the model is run with the alternative accumulation rates

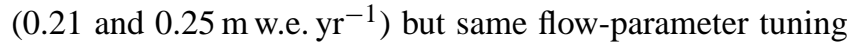
as used to fit the Tambora eruption with the $0.23 \mathrm{mw}$ we. $\mathrm{yr}^{-1}$ accumulation rate, the age offset for the Tambora eruption depth-age marker is $>17 \mathrm{yr}$ (Fig. S5 in the Supplement), which is significantly larger than the estimated uncertainty on our annual layer count.

As the initial layer count did not need to be adjusted to match the tritium marker age tie point, dating is accurate to within \pm 1 yr between 2006 and 1964 AD (19 m depth). The age offset between the the initial annual layer count and the date of deposition from Mt. Tambora was $8 \mathrm{yr}$ and provides an age uncertainty estimate at $61.1 \mathrm{~m}$ depth. For comparison, annual layer counting was continued until $90 \mathrm{~m}$ depth, after which it became challenging to identify annual layers. The age difference between the annual layer count and the

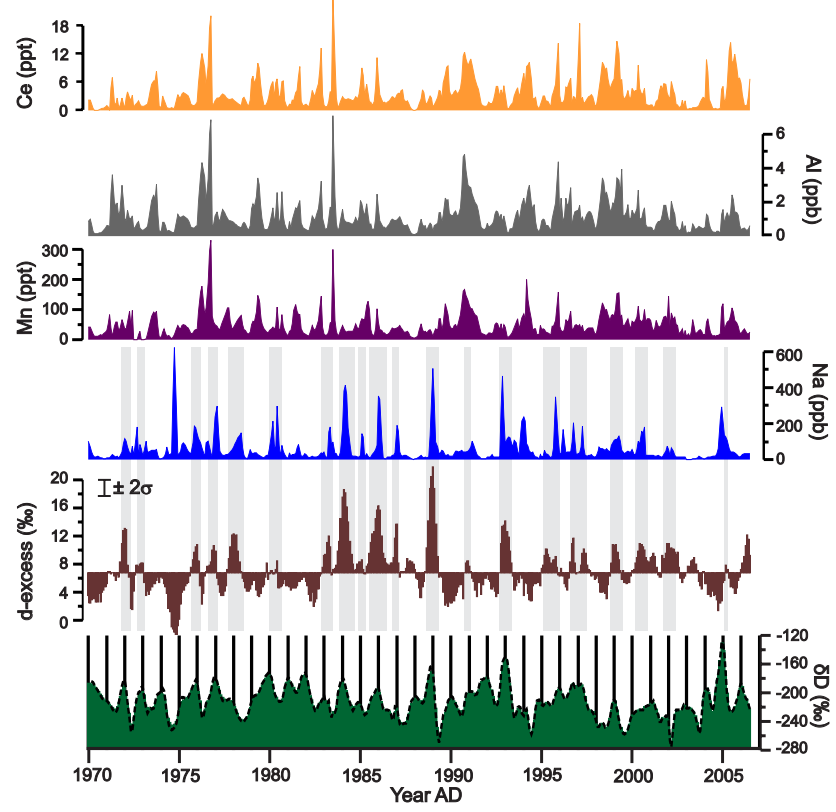

Fig. 4. Stable isotope and chemistry data for the time period 19702006 AD of the MES ice core. All the time series have been resampled to monthly resolution. Vertical black lines on the $\delta \mathrm{D}$ plot locate annual layers. Back-diffused $\delta \mathrm{D}$ data are plotted for comparison (dashed black line). The d-excess time series is plotted around the 1970-2006 mean value. $\delta \mathrm{D}$ analytical error bars are too small to plot, and the d-excess analytical error is indicated. Shaded bars highlight d-excess values exceeding the 1970-2006 mean with associated Na peaks (grey shading).

ice flow model $\left(0.23 \mathrm{~m}\right.$ w.e. $\left.\mathrm{yr}^{-1}\right)$ at $90 \mathrm{~m}$ was $9 \mathrm{yr}$. Although these dating methods are not entirely independent, this difference provides an estimate of the cumulative dating error at $90 \mathrm{~m}$ depth. However, the outcome of the ice flow model is heavily dependent on both the prescribed accumulation rate and the assumption that it is constant in time. Therefore, according to the tests described above, the absolute age uncertainty could be as high as $\pm 50 \mathrm{yr}$ at $100 \mathrm{~m}$ depth and $\pm 130 \mathrm{yr}$ at $120 \mathrm{~m}$ depth.

\section{Results}

\subsection{Stable isotopes}

$\delta \mathrm{D}$ and $\delta^{18} \mathrm{O}$ records of the MES ice core display welldeveloped seasonal cycles (Fig. $5, \delta \mathrm{D}$ shown). $\delta \mathrm{D}$ varies between a mean summer (1 January, fixed by dating) maximum of $-198 \%$ and a mean winter (1 July) minimum of $-224 \%$ in the 1970-2006 AD time period (Fig. 5). The $\delta \mathrm{D}$ and d-excess time series show different interannual variability (Fig. 4), and regression of their annual mean or maximum values produces no significant correlation.

In the long-term $\delta \mathrm{D}$ record of the MES ice core, the only deviations below the 1950-2006 AD mean value of $>4 \mathrm{yr}$ 


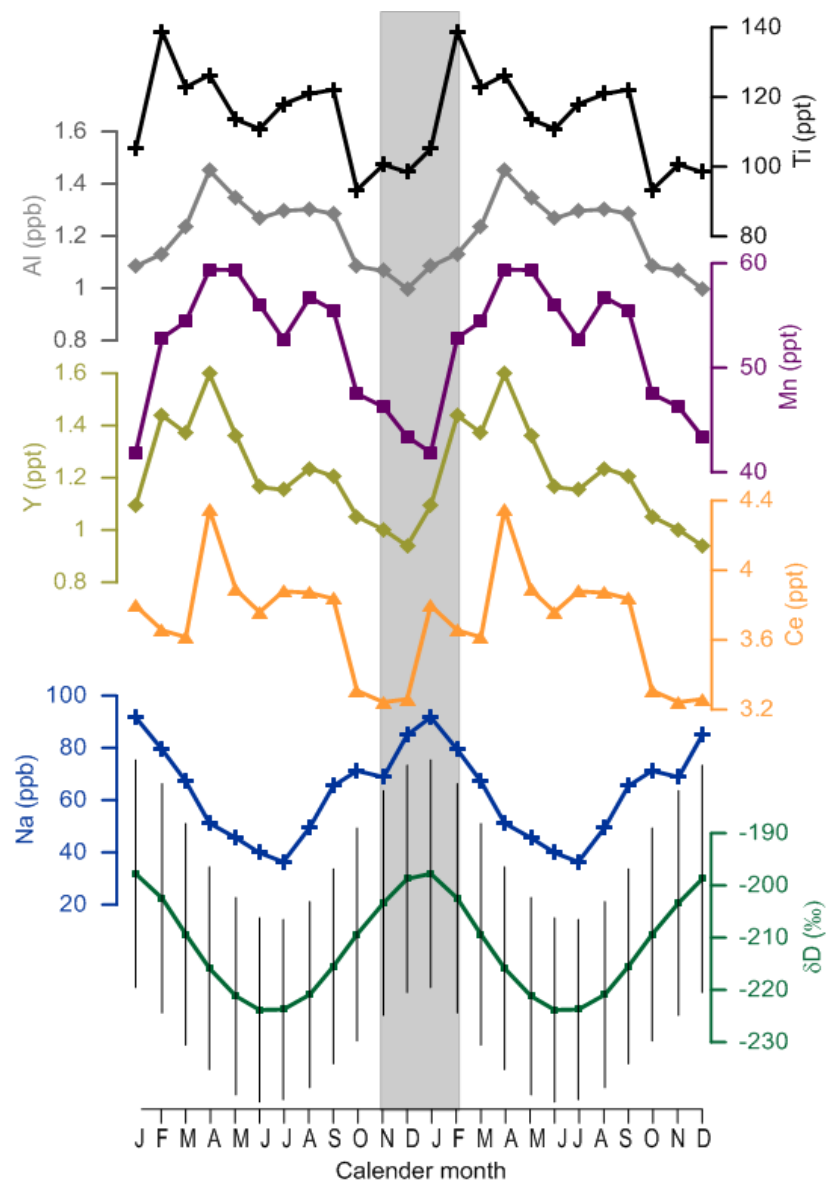

Fig. 5. Mean seasonal cycles of $\delta \mathrm{D}$, marine aerosol $(\mathrm{Na})$ and lithophile elements (Ce, Y, Mn, Al and Ti) for 1970-2005 AD. Two cycles are plotted to aid viewing. $\delta \mathrm{D}$ has been back-diffused to correct for minor changes in amplitude and phasing of seasonal cycles resulting from molecular diffusion. $\delta \mathrm{D}$ error bars represent the standard deviation of each monthly mean value. Standard deviations of the monthly means are greater than the amplitude of seasonal cycles for $\mathrm{Na}, \mathrm{Ce}, \mathrm{Y}, \mathrm{Mn}, \mathrm{Al}$ and $\mathrm{Ti}$.

duration occur prior to $1850 \mathrm{AD}$ (Fig. 6). The most notable of these low $\delta \mathrm{D}$ periods are identified on Fig. 6 by the letters $\mathrm{A}$ to $\mathrm{E}$ and dated as $1492-1518 \mathrm{AD}, 1613-1637 \mathrm{AD}$, 1672-1700 AD, 1757-1778 AD and 1831-1843 AD, but we note that these absolute ages are subject to error (Section 3.3). The mean $\delta \mathrm{D}$ of the pre- $1850 \mathrm{AD}$ period is $6.2 \%$ lower than that of the post-1850 AD record (Table 2). The pre- and post- $1850 \mathrm{AD}$ periods also exhibit contrasting trends in $\mathrm{d}-$ excess. The 5-yr running mean of the d-excess record oscillates about the 1950-2006 AD mean value from 1875 to $2006 \mathrm{AD}$, whereas prior to $1875 \mathrm{AD}$ the 5 -yr mean remains almost consistently above the 1950-2006 AD mean, the only exception occurring at ca. $1795 \mathrm{AD}$. This relatively elevated state of d-excess is maintained back through the record until at least $1658 \mathrm{AD}$. The d-excess mean is $1.5 \%$ o higher between 1658 to $1875 \mathrm{AD}$ compared to the following time period, although this value is close to the analytical uncertainty for this section of the record (Sect. 2.3.1). Unfortunately, at $92 \mathrm{~m}$ depth in the ice core (1658 AD), the technique used for isotopic analysis was changed from mass spectrometry to laser spectroscopy and inter-calibration differences between the two instruments make comparison of absolute dexcess values difficult. The d-excess values measured by the LGR laser instrument have been adjusted for offsets between the instruments (Supplement) before plotting in Fig. 6. The LGR data suggest that the relatively elevated d-excess values, which characterised the 1658-1875 AD time period, do not persist further back in the record. However, the apparent switch in d-excess behaviour at $1658 \mathrm{AD}$ is coincident with the change in measurement technique and, therefore, may be be an analytical artefact.

\subsection{Major ion and trace element chemistry}

The ICP-MS dataset and its component variables (elements) have negatively skewed distributions with small numbers of outlying points of high concentration (Fig. 7). These points are outliers in a statistical sense, but they show no evidence of contamination or analytical artefacts. Here we use the minimum covariance determinant (MCD) estimator to produce robust correlation matrices not influenced by outliers (Fig. 8a). Both the pre-1850 and post-1850 AD sections of the ice core record show clear delineation of marine and terrestrial (hereafter lithophile) elements. $\mathrm{Na}, \mathrm{Mg}$ and $\mathrm{Sr}$ are strongly correlated $\left(R^{2}>0.95\right)$, and concentration ratios of these elements correspond to the seawater concentration ratios, indicating a marine source. Concentrations of lithophile elements $\mathrm{Al}, \mathrm{Ti}, \mathrm{Mn}, \mathrm{Rb}, \mathrm{Ba}, \mathrm{Y}, \mathrm{La}$ and $\mathrm{Ce}$ all inter-correlate at $R^{2}>0.6$, whilst $\mathrm{V}$ exhibits some weak correlation with both marine and lithophile elements. As, Cs, Pr, Tl, Bi, Th and $\mathrm{U}$ are not considered because levels were frequently below the ICP-MS detection limit.

Marine and lithophile elements show different temporal trends in concentration variability between 1970 and 2006 AD (Fig. 4). The mean annual cycles of element concentration suggest that the timings of marine and lithophile element deposition are anti-phased. Annual maximum $\mathrm{Na}$ concentrations (92 ppb mean) generally occur in summer, coincident with the annual peaks in $\delta \mathrm{D}$ (Fig. 5). This is the opposite phasing of annual $\mathrm{Na}$ peaks to that seen in ice cores from the Antarctic interior (e.g. Legrand and Mayewski, 1997), which record Na maxima in winter months. In contrast, the lithophile elements exhibit concentration maxima in the autumn and winter months (Fig. 5, Ce, Y, Al, Mn, Ti shown). The Al mean seasonal cycle of 1970-2006 AD shows a $45 \%$ higher concentration in winter relative to summer. Despite the existence of significant interannual variability in the amplitude of the seasonal cycle (Fig. 4), the phasing is consistent across the 1970-2006 AD period and is evident for all lithophile elements. 


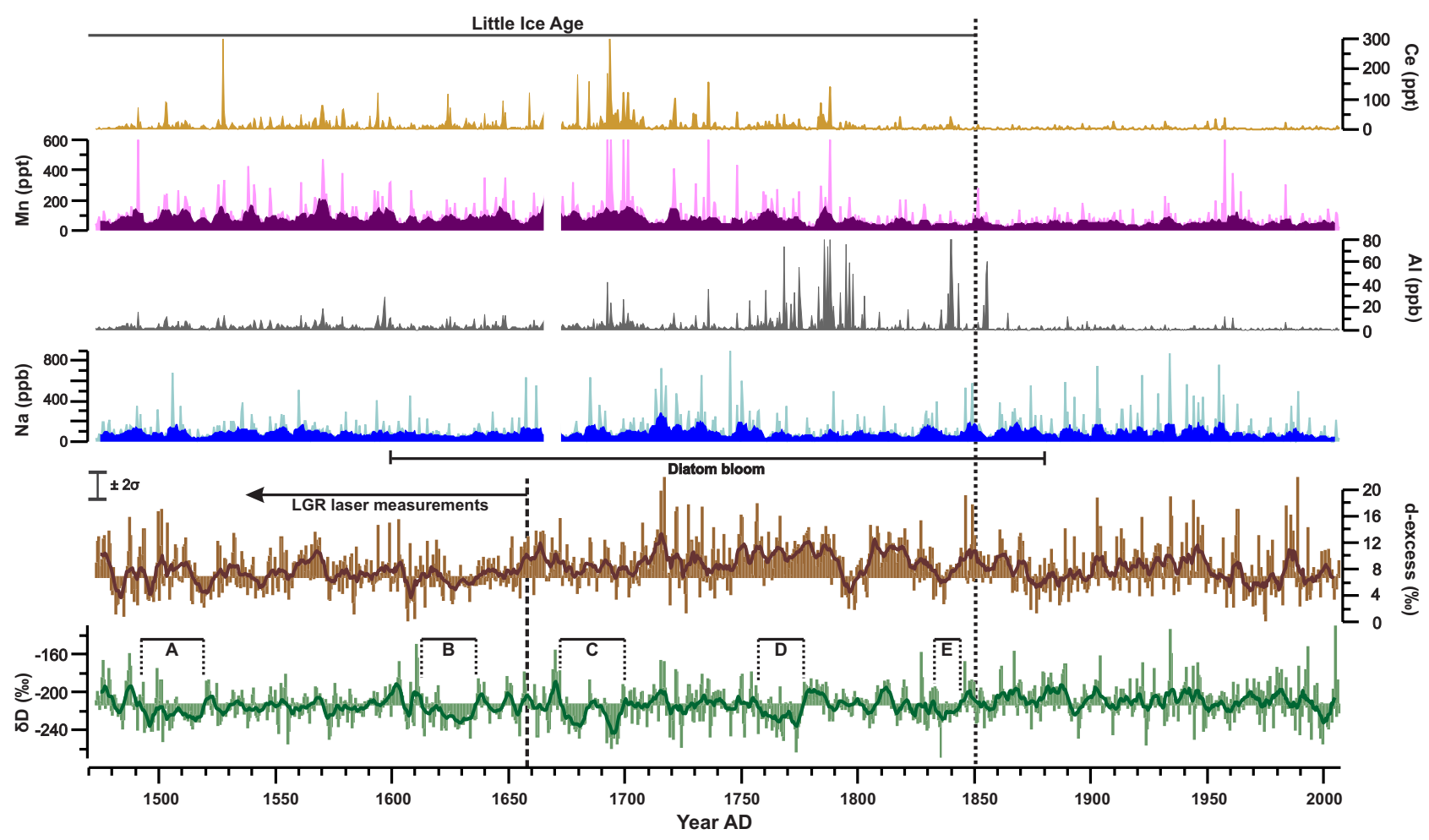

Fig. 6. Stable isotope and chemistry records from the MES ice core re-sampled to 2 samples $\mathrm{yr}^{-1}$. 5 yr smoothed time series are plotted in bold colours for all time series except $\mathrm{Al}$ and Ce. $\delta \mathrm{D}$ and d-excess are plotted around 1950-2006 AD mean values. Letters A-E indicate anomalously cold time periods referred to in the text. LGR laser measurements of $\delta \mathrm{D}$ and d-excess have been adjusted (Supplement). The d-excess analytical error applicable to the entire dataset is indicated. Al plot is clipped at $80 \mathrm{ppb}$ and Mn plot is clipped at $600 \mathrm{ppt}$. Timing of a diatom bloom reported by Leventer and Dunbar (1988) in four sediment core records from the north-west of Ross Island in McMurdo Sound is indicated. The gap in ICP-MS data is due to the removal of anomalously high chemistry concentrations relating to a tephra layer in the ice core.

Marine and lithophile element concentration records show markedly different variability over the last five centuries in the MES record. Over the entire record, marine element concentrations remained relatively constant with no prominent amplitude changes (Fig. 6, Na shown). In contrast, lithophile element records clearly exhibit higher magnitude concentrations prior to $1850 \mathrm{AD}$ compared to post $1850 \mathrm{AD}$ (Fig. 6 and Table 2, Al, Ce and $\mathrm{Mn}>60 \%$ higher prior to $1850 \mathrm{AD}$ ). To test whether or not this increase in lithophile element concentrations is in fact reflected in the entire dataset, not just in several outlying data points, we plot notched boxplots of successive 50-yr intervals of the MES record (Fig. 7). This method allows identification of significantly different median values, which are not themselves influenced by outliers. The notched boxplots confirm our observations of the $\mathrm{Na}$ record - no 50-yr interval has a significantly different median from any other in the record. However, the notched boxplots show that median concentrations of $\mathrm{Al}, \mathrm{Mn}$ and $\mathrm{Ce}$ are significantly $(p<0.05)$ higher for every 50-yr interval between 1500 and 1800 AD compared to 1800 to 2000 AD. The $1800-1850$ AD interval does not have significantly different median values for $\mathrm{Al}, \mathrm{Mn}$ and Ce compared to 1850-2000 AD, despite some spikes in $\mathrm{Al}$ and $\mathrm{Ti}$ concentration reaching values an order of magnitude above the baseline (Fig. 6, Al shown). This highlights that, whilst the anomalously high lithophile concentration data points are outliers statistically, they are valid geochemical analyses that can provide useful information about paleo-environmental conditions.

Substantial variability between the behaviour of different lithophile elements, not observed in the record of the last $35 \mathrm{yr}$ (Fig. 4), can be discerned in the long-term record if the entire dataset is considered (Fig. 6). For example, the mean Ce concentrations decreased by $74 \%$ after $1850 \mathrm{AD}$, whilst mean Mn concentration decreased by only $38 \%$ (Table 2 ). A correlation matrix of the raw trace element data for the pre-1850 AD period displays three groups of lithophile elements: $R^{2}$ values of $>0.8$ are produced between $\mathrm{Ti}$ and $\mathrm{Al}$; $R^{2}>0.7$ between $\mathrm{Mn}$ and $\mathrm{Rb}$; and $R^{2}>0.9$ between $\mathrm{Y}$, La and Ce $(p<0.01)$ (Fig. 8b). Figures 4, 6 and 7 display data for a representative element from each of these groups. In contrast, the correlation matrix for the post-1850 AD period shows inter-correlation of all the lithophile elements, except $\mathrm{Al}$ and $\mathrm{Ba}$, at $R^{2}>0.5(p<0.01)$ (Fig. $\left.8 \mathrm{~b}\right)$. 


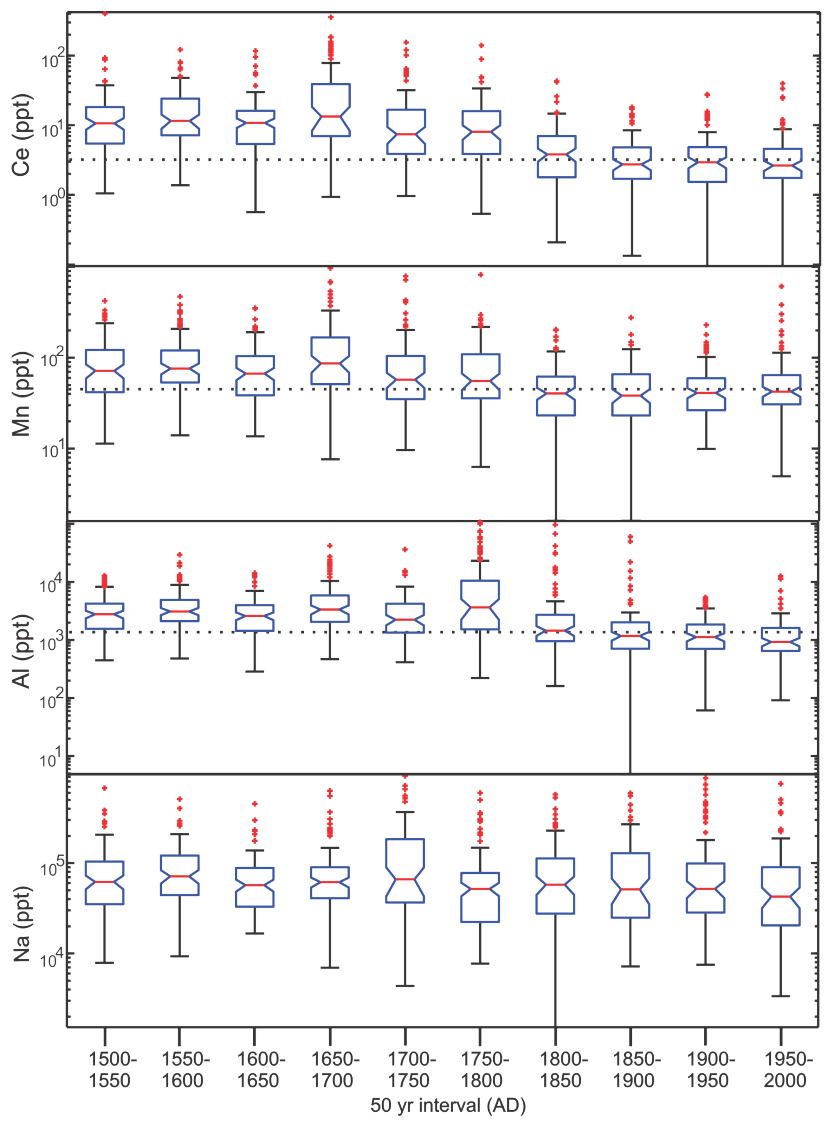

Fig. 7. Notched boxplots of chemical element concentrations (resampled to 2 samples $\mathrm{yr}^{-1}$ ) for 50 -yr intervals of the MES record. The extent of the blue box defines the inter-quartile range (IQR), and the red horizontal line is the median value. Medians values of two time intervals are significantly different $(p<0.05)$ if boxplot notches around the median lines do not overlap. Black whiskers denote range of $1.5 \times \mathrm{IQR}$, and data points that lie outside this range are defined as statistical outliers (red crosses). Horizontal black dotted line locates upper edge of notch for 1850-1900 AD interval.

Methylsulphonate concentrations in the MES ice core are available for the section of record dating from 1795 to $2006 \mathrm{AD}$ and vary between 1 and $187 \mathrm{ppb}$ about a mean of $54 \mathrm{ppb}$ (Fig. 9). A period of significantly higher concentrations is identifiable between 1825 and 1875 AD. The mean concentration of this period is $81 \%$ higher than that recorded between 1876 and $2006 \mathrm{AD}$.

\subsection{Lithophile elements and katabatic wind strength}

Lithophile trace element concentrations in the MES ice core are significantly higher than those measured on snow or ice samples from inland Antarctica. For example, Hur et al. (2007) reported mean concentrations of $\mathrm{Al}, \mathrm{V}, \mathrm{Mn}$ and $\mathrm{Ba}$ at Lambert Glacier, East Antarctica, from 1998 to 2002 AD, as $165 \mathrm{ppt}, 0.46 \mathrm{ppt}, 3.7 \mathrm{ppt}$ and $2.4 \mathrm{ppt}$ respectively, whilst the mean concentrations from MES for the equivalent time

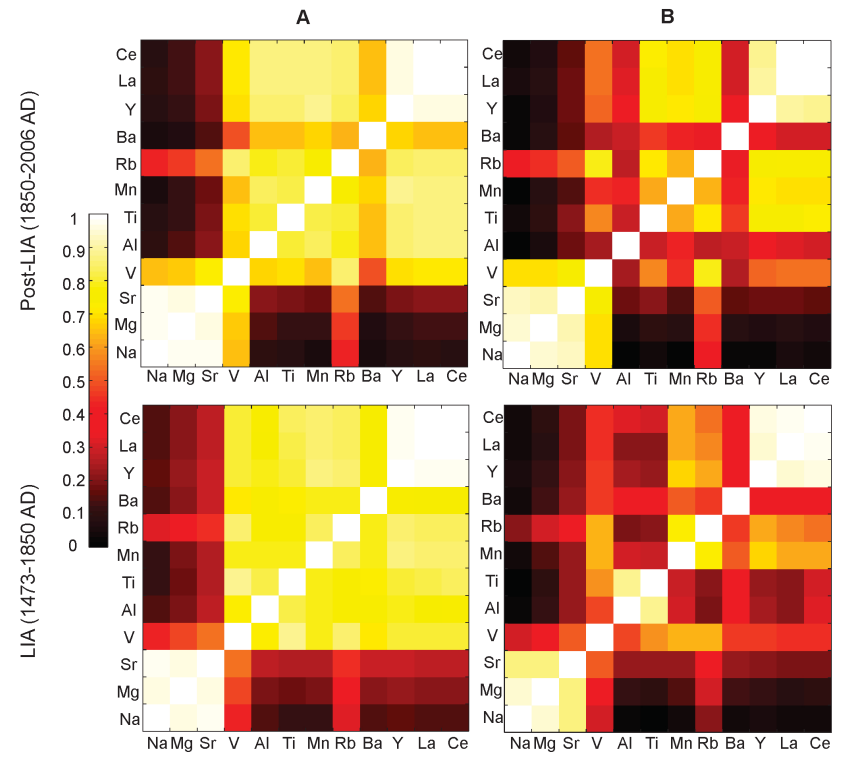

Fig. 8. Correlation matrices of ICP-MS element concentration data from post-LIA (1850-2006) (upper panel) and LIA (1474-1850) (lower panel). Matrices are shaded according to the value of the correlation coefficient. (A) Matrices on the left panel are correlation results of minimum covariance determinant (MCD) estimator ( $h=0.75 n)$, a robust method that removes the effect of statistical outliers (Rousseeuw, 1984). (B) Matrices on the right panel display correlations performed on raw data of non-Gaussian distribution.

period are $1456 \mathrm{ppt}, 4.0 \mathrm{ppt}, 72.5 \mathrm{ppt}$ and $33.1 \mathrm{ppt}$ - higher by more than an order of magnitude. The outcome is the same if MES V, Mn, Ba and Pb concentrations are compared to those reported for samples dating back to the early 19th century from Coats Land, East Antarctica (Planchon et al., 2002).

Lithophile element concentrations reflect the level of mineral dust present in ice core samples (Petit et al., 1981; Rhodes et al., 2011). Unlike most other Antarctic ice core locations, MES has several areas of outcropping rock located within $160 \mathrm{~km}$, in the McMurdo Dry Valleys and along the Transantarctic Mountains (Fig. 1). We therefore surmise that the atypically high lithophile element concentrations recorded at MES are the result of mineral dust input from local (100 s of km distance away), rather than global (1000 s of km distance away), dust sources. Several studies of mineral dust deposition within the southwestern Ross Sea region support this assumption (Ayling and McGowan, 2006; Dunbar et al., 2009; Bull, 2009). We do not attempt to relate the lithophile element signatures recorded in the ice core to the various dust lithologies of the region as previous work has shown this does not provide a reliable indicator of provenance (Rhodes et al., 2011).

Increased lithophile element concentrations during the autumn and winter months (Fig. 5) indicate that strong $\left(>35 \mathrm{~m} \mathrm{~s}^{-1}\right.$ at Scott Base; data available at www.cliflo.co. nz) katabatic winds originating from the continental interior 
Table 2. Mean (italicised), median and range (in parentheses) of selected stable isotopic and chemistry parameters within specified time intervals of the MES ice core record. $\delta \mathrm{D}$ and d-excess data measured by LGR laser instrument have been adjusted (Supplement).

\begin{tabular}{|c|c|c|c|}
\hline & 1950-2006 & 1850-2006 (post LIA) & 1474-1850 (LIA) \\
\hline$\delta \mathrm{D}(\% o)$ & $\begin{array}{l}-211.3,-213.1 \\
(-254.1 \text { to }-130.4)\end{array}$ & $\begin{array}{l}-209.0,-209.5 \\
(-256.1 \text { to }-130.4)\end{array}$ & $\begin{array}{l}-215.2,216.0 \\
(-269.3 \text { to }-150.3)\end{array}$ \\
\hline d-excess $(\% o)$ & $\begin{array}{l}7,6 \\
(0 \text { to } 22)\end{array}$ & $\begin{array}{l}8,7 \\
(0 \text { to } 22)\end{array}$ & $\begin{array}{l}8,8 \\
(-1 \text { to } 22)\end{array}$ \\
\hline $\mathrm{Na}(\mathrm{ppb})$ & $\begin{array}{l}74.5,40.9 \\
(2.15 \text { to } 757)\end{array}$ & $\begin{array}{l}95.0,47.7 \\
(2.15 \text { to } 869)\end{array}$ & $\begin{array}{l}93.9,60.3 \\
(1.54 \text { to } 924)\end{array}$ \\
\hline $\mathrm{Al}(\mathrm{ppb})$ & $\begin{array}{l}1.37,0.90 \\
(0.09 \text { to } 12.6)\end{array}$ & $\begin{array}{l}1.93,1.09 \\
(<\mathrm{DL} \text { to } 60.3)\end{array}$ & $\begin{array}{l}5.20,2.55 \\
(0.16 \text { to } 107)\end{array}$ \\
\hline Ti (ppt) & $\begin{array}{l}117,81 \\
(<\mathrm{DL} \text { to } 857)\end{array}$ & $\begin{array}{l}119,80 \\
(<\mathrm{DL} \text { to } 1276)\end{array}$ & $\begin{array}{l}518,245 \\
(<\mathrm{DL} \text { to } 15029)\end{array}$ \\
\hline $\mathrm{Mn}(\mathrm{ppt})$ & $\begin{array}{l}62.9,42.5 \\
(5 \text { to } 609)\end{array}$ & $\begin{array}{l}54.9,41.5 \\
(<\text { DL to } 609)\end{array}$ & $\begin{array}{l}92.7,62.9 \\
(<\mathrm{DL} \text { to } 969)\end{array}$ \\
\hline $\mathrm{Rb}(\mathrm{ppt})$ & $\begin{array}{l}4.0,3.3 \\
(<\mathrm{DL} \text { to } 22.1)\end{array}$ & $\begin{array}{l}4.1,3.2 \\
(<\mathrm{DL} \text { to } 21.6)\end{array}$ & $\begin{array}{l}8.2,4.1 \\
(<\mathrm{DL} \text { to } 66.2)\end{array}$ \\
\hline $\mathrm{La}(\mathrm{ppt})$ & $\begin{array}{l}2.1,1.4 \\
(<\mathrm{DL} \text { to } 21.6)\end{array}$ & $\begin{array}{l}2.2,1.5 \\
(<\mathrm{DL} \text { to } 21.6)\end{array}$ & $\begin{array}{l}8.2,4.1 \\
(>\mathrm{DL} \text { to } 196)\end{array}$ \\
\hline $\mathrm{Ce}(\mathrm{ppt})$ & $\begin{array}{l}4.1,2.6 \\
(>\mathrm{DL} \text { to } 39.7)\end{array}$ & $\begin{array}{l}4.2,2.8 \\
(>\mathrm{DL} \text { to } 39.7)\end{array}$ & $\begin{array}{l}16.8,8.7 \\
(0.21 \text { to } 401)\end{array}$ \\
\hline
\end{tabular}

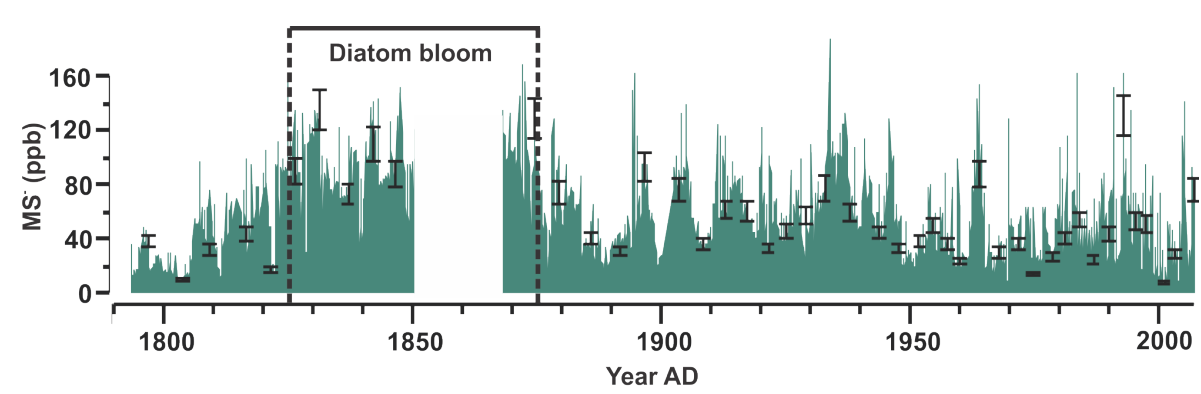

Fig. 9. $\mathrm{MS}^{-}$data for the MES ice core plotted with the timing of a diatom bloom reported by Leventer and Dunbar (1988) in two sediment core records from McMurdo Sound, to the west of Ross Island. Representative analytical error bars $( \pm 2 \sigma)$ are displayed on selected points. A gap in the time series exists because some samples were not analysed for $\mathrm{MS}^{-}$concentration.

are required to transport additional local mineral dust material to MES. To further investigate this relationship, we correlate the ice core data with NCEP/NCAR reanalysis meridional wind strength (Kalnay et al., 1996). In this region of Antarctica, the meridional (south to north) component of the wind field is an approximation of katabatic wind flow (Fig. 10a). No significant correlation between wind speed and lithophile element concentration could be achieved for the entire time period for which reliable Antarctic NCEP/NCAR data are available (1979-2006 AD). However, when individual decades are studied, a significant correlation with the MES Al concentration is observed for the 1990-2000 AD time period (Fig. 10b). In contrast to the 1980s, the 1990s were characterised by a relatively strong teleconnection between the El Niño Southern Oscillation and Antarctica (Fogt and Bromwich, 2006). This led to enhanced katabatic flow speeds in the Ross Sea region (Bertler et al., 2004a), and a stronger signal in the MES katabatic wind proxy. The area of significant correlation includes the Transantarctic Mountains to the south of MES, a source region for katabatic winds to the site, which further confirms katabatic flow as the mechanism for mineral dust transport to MES.

As lithophile element concentrations in the MES ice core record are proxies for katabatic wind strength, we conclude that the elevated lithophile concentrations prior to $1853 \mathrm{AD}$ $( \pm 8 \mathrm{yr})$ indicate greater katabatic wind activity. Based on this transition and a cooling trend prior to $1850 \mathrm{AD}$ suggested 

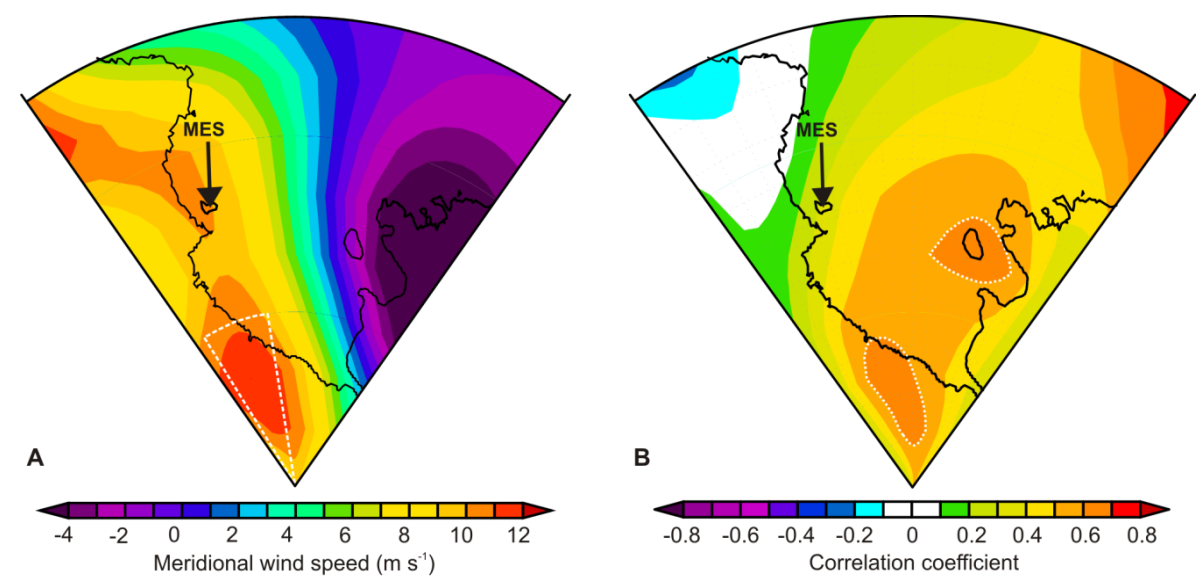

Fig. 10. (A) NCEP/NCAR reanalysis $850 \mathrm{mb}$ meridional wind composite mean for the winter months (JJA) of 1979-2006 AD across the Ross Sea region $\left(90-70^{\circ} \mathrm{S}, 150-220^{\circ} \mathrm{E}\right)$. White dashed line defines the source region of meridional winds arriving at MES. (B) Spatial correlation pattern between meridional wind $(850 \mathrm{mb})$ and MES Al concentration record for the winter months (JJA) of 1990-2000 AD across the Ross Sea region. White dashes outline region of significant correlation $(p<0.025, n=10)$.

by $\delta \mathrm{D}$ (discussed below), we equate the pre-1850 AD portion of the MES record to the LIA, in line with several other Antarctic ice core records (Bertler et al., 2011; Masson et al., 2000; Kreutz et al., 1997; Mosley-Thompson, 1995).

Formulating an approximation of how much stronger katabatic winds were is challenging, principally because the relationship between dust entrainment and wind speed is not linear (Bagnold, 1941; Pye, 1987; Schulz et al., 1998). However, as the elevated lithophile element concentrations of the LIA are not repeated in the post-1850 AD ice core record, we can assume that wind speeds did not reach such strength again. At Scott Base the maximum daily gust speed recorded since 1972 was $57.7 \mathrm{~m} \mathrm{~s}^{-1}$ from the south, so we conclude that LIA maximum wind speeds must have significantly exceeded this value. Evidence for stronger katabatic winds across East Antarctica during this interval of the LIA is also found in an ice core microparticle record from the South Pole (Mosley-Thompson, 1995).

By examining the behaviour of the three groups of lithophile elements identified in Sect. 4.2 and their links to mineralogy and wind speed, considerable climate variability within the LIA is revealed. Al (Figs. 6 and 7) and Ti (Table 2) show increased median concentrations coupled with discrete periods of dramatic concentration increases of several orders of magnitude during the LIA. These elements are predominantly sourced from complex silicate minerals, such as feldspars, which have relatively high densities and grain sizes, and therefore require higher wind velocities to initiate transport in suspension (Bagnold, 1941). The discrete periods of increased $\mathrm{Al}$ and $\mathrm{Ti}$ concentrations therefore represent the most extreme wind speeds of the LIA period. In contrast, the lithophile elements of the second group, $\mathrm{Mn}$ and $\mathrm{Rb}$ (Table 2), which show statistically higher median concentration increases (Fig. 7) but relatively muted concentration spikes during the LIA, are common in Fe-Mn oxyhydroxides and sheet silicate minerals such as micas and clays. The relatively low densities and tendency of these phases to rapidly weather to sheet-like particles of a low, uniform grain size result in a lower wind velocity threshold to initiate transport of these minerals in suspension (Bagnold, 1941). It can therefore be assumed that $\mathrm{Mn}$ and $\mathrm{Rb}$ concentrations in the MES ice core do not reflect maximum wind strength in the LIA. The third group of lithophile elements, consisting of $\mathrm{La}, \mathrm{Ce}$ and $\mathrm{Y}$, shows characteristics of both the other two groups. During discrete time periods of the LIA, concentrations increase by an order of magnitude but the timings of these extreme events do not always match that of the greatest increases in $\mathrm{Al}$ (Fig. 6) and Ti. Similarly to Mn, La, Ce and Y are abundant in ferromanganese oxyhydroxide minerals but they are also common impurities in apatite. Given this information, the lithophile element records suggest that between 1800 and $1853 \mathrm{AD}$ the prevalent or mean katabatic wind speed decreased to a level similar to that of the present day but that there were still some anomalously strong wind events capable of transporting Al- and Ti-rich silicate minerals.

\subsection{Stable isotopes and temperature}

The MES $\delta \mathrm{D}$ record suggests that colder temperatures, as well as stronger winds, than those experienced in the past $50 \mathrm{yr}$ prevailed during the LIA. Decreases in $\delta \mathrm{D}$ indicate cooler air temperatures (Craig, 1961; Dansgaard, 1964), and all the periods of significant deviations below the 1950 to 2006 AD mean identified on Fig. 6 (letters A-E) date from the LIA. Additionally, sustained cold temperatures appear to be linked to the strongest katabatic flow events as the three most recent cold periods identified in the MES ice core (Fig. 6, letters C-E) occur synchronously with the strongest 
wind events of the LIA, as recorded by the concentrations of $\mathrm{Al}$ (Fig. 6) and Ti.

Direct calibration of the stable isotopic paleothermometer for the MES ice core record is challenging, because the weather conditions at MES are significantly different to those of nearby weather stations and the extreme topography of Ross Island is not well represented in gridded reanalysis datasets. As an alternative, we employ the Taylor Dome $\delta$-borehole temperature calibration of $4 \pm 1.5 \% \circ \delta \mathrm{D}$ per ${ }^{\circ} \mathrm{C}$ (Steig et al., 1998) to estimate the degree of cooling experienced at MES during the LIA. Taylor Dome is also located in the Ross Sea region (Fig. 1a) and is the most proximal ice core for which a local $\delta$-temperature slope has been established. The difference between the mean $\delta \mathrm{D}$ of the LIA and the post-LIA period is $6.2 \%$ (Table 2), which equates to a mean cooling of $1.6 \pm 0.60^{\circ} \mathrm{C}$ during the LIA. The extensive review of Antarctic stable isotopic signatures by MassonDelmotte et al. (2008) found that $\delta$-temperature slopes can vary by $20 \%$ between localities, which increases the uncertainty on our cooling estimate to $\pm 1.41^{\circ} \mathrm{C}$. Our estimate agrees with the $\sim 2{ }^{\circ} \mathrm{C}$ cooling reported for this time period at Victoria Lower Glacier in the northern McMurdo Dry Valleys (Fig. 1c) (Bertler et al., 2011). Furthermore, a temperature record obtained from the West Antarctic Ice Sheet (WAIS) Divide ice core borehole also found evidence for $0.52 \pm 0.28^{\circ} \mathrm{C}$ cooling between 1400 and $1800 \mathrm{AD}$ relative to the last $100 \mathrm{yr}$ (Orsi et al., 2012).

\subsection{Marine aerosol input}

The $\mathrm{Na}^{+} / \mathrm{SO}_{4}^{2-}$ values of MES ice core samples are all lower than that of seawater, with only one exception. The mean $\mathrm{Na}^{+} / \mathrm{SO}_{4}^{2-}$ is 0.56 , compared to $\mathrm{Na}^{+} / \mathrm{SO}_{4}^{2-}$ seawater of 3.97 . This is consistent with marine aerosol sourced from the open ocean via the bubble bursting mechanism, rather than from frost flowers entrained from the sea ice surface (Rankin et al., 2004). The timing of marine aerosol deposition during the summer months (Fig. 5) of minimum sea ice extent is also suggestive of an open water source. We attribute the deposition of marine aerosol at MES to synoptic- or mesoscale cyclonic systems (Sinclair et al., 2010). The opposite seasonal cycle of lithophile and marine element concentrations at MES (Fig. 5) supports the assignment of two different meteorological systems, katabatic winds and marine cyclones respectively, as transport mechanisms for these chemical species.

We observe that in the 1970-2006 AD record d-excess peaks greater than the long-term mean have corresponding peaks in $\mathrm{Na}$ concentration in $90 \%$ of cases (Fig. 4, grey shaded bars). Furthermore, the maximum summer values of $\mathrm{Na}$ and d-excess between 1970 and $2006 \mathrm{AD}$ are significantly correlated $\left(R^{2}=0.58, p<0.01\right)$ suggesting a common source. Deuterium excess is thought to be controlled by conditions at the moisture source, which are principally relative humidity, sea surface temperature (SST) and wind speed (Merlivat and Jouzel, 1979; Petit et al., 1991), but is also controlled by the degree of super-saturation during snow flake formation and is therefore related to cloud temperature (Jouzel and Merlivat, 1984). As a result, detailed delineation of potential oceanic moisture source regions, coupled with isotopic modelling, is required to understand the origin of the MES d-excess signal. However, we have established that more positive d-excess values are associated with inputs of marine aerosol sourced from open water. Therefore, we tentatively speculate that more positive d-excess values are related to increased cyclonic activity in the Ross Sea region, which promotes marine aerosol generation by bubble bursting (Kreutz et al., 2000). A detailed study of back trajectories conducted for a site close to the Byrd Glacier (Fig. 1b) identified a statistical link between ice core d-excess and the frequency of oceanic cyclone systems, albeit with several complicating factors (Markle et al., 2012). We speculate that the elevated d-excess values observed prior to $1875 \mathrm{AD}$, until at least $1658 \mathrm{AD}$ (Fig. 6), could be the result of more frequent intrusion of marine cyclones, but more evidence is required to evaluate this hypothesis. One argument against a stronger cyclonic intrusion is the lack of any accompanying increase in $\mathrm{Na}$ concentration (Fig. 8) prior to $1875 \mathrm{AD}$, which we would expect given the observed relationship between d-excess and $\mathrm{Na}$ over the past $35 \mathrm{yr}$.

\subsection{Ross Sea polynya}

The $\mathrm{MS}^{-}$record of the MES ice core provides a proxy record of Ross Sea polynya area (Rhodes et al., 2009). Although it has limited temporal coverage, the higher concentrations recorded between 1825 and $1875 \mathrm{AD}$ indicate that the polynya area was greater during this time (Fig. 9). As variability in katabatic wind strength has been directly linked to polynya size (Morales Maqueda et al., 2004), we conclude that the stronger katabatic winds of the LIA were responsible for the increase in polynya size. Increased polynya area exerts a positive feedback on marine primary productivity (Arrigo and van Dijken, 2004). By extrapolating the linear relationship between $\mathrm{MS}^{-}$concentration $(x)$ and primary production rate $(y)$ established by Rhodes et al. (2009) $(y=1.35 x-3.41)$, we calculate that between 1825 and $1875 \mathrm{AD}$ primary productivity rates were approximately $80 \%$ higher than the post- 1875 AD level.

Diatom abundances from two sediment cores retrieved from the west of Ross Island reveal a period of increased primary productivity between 1825 and $1880 \mathrm{AD}$ (Leventer and Dunbar, 1988). This timing closely corresponds to the interval of higher $\mathrm{MS}^{-}$concentrations observable in the MES record (Fig. 9) suggesting that both records respond to the same signal. These sediment cores were dated by the extrapolation of accumulation rates for the first $100 \mathrm{yr}$ of the record, calculated from $\mathrm{Pb}-210$ measurements. All time ranges are referred to as "approximate" by Leventer and Dunbar (1988), 
and dating errors are likely to be greater than those of the MES core.

A second, more prolonged, time period (1600-1875 AD) of increased open water diatom populations was identified in four sediment cores retrieved from the north and northwest of Ross Island (Leventer and Dunbar, 1988). These records indicate that the Ross Sea polynya was greater in area, or temporally more persistent, through much of the time covered by the MES ice core and consequently much of the LIA. The 1600-1875 AD interval includes all of the low temperature, high wind speed events recorded in the core. We propose that colder temperatures in the Ross Sea region led to stronger katabatic flows that maintained a spatially larger and/or more temporally persistent polynya between 1600 and $1850 \mathrm{AD}$. We also have evidence for a greater polynya area between 1850 and $1875 \mathrm{AD}$ relative to the ensuing time, but $\delta \mathrm{D}$ and lithophile element concentrations provide no indication of colder temperatures or windier conditions beyond $1853 \mathrm{AD}$. Here the d-excess record becomes intriguing because the time interval of relatively high values persists until $1875 \mathrm{AD}$, suggesting that whatever process is controlling dexcess, be it cyclonic activity or something else, is linked to polynya area. Further investigation into the controls on dexcess at MES is required to decipher this signal.

\section{Conclusions}

Stable isotope, major ion and trace element chemistry records from the MES ice core document the last five centuries of climate in the southwestern Ross Sea region of Antarctica at sub-annual resolution. Dating of the record is accomplished by a combination of annual layer counting and ice flow modeling. Absolute dating uncertainty could exceed $\pm 50 \mathrm{yr}$ for the pre-1816 AD record as no age tie points are distinguishable and dating relies on a 1-D flow model. Examination of the monthly resolution record of the last $35 \mathrm{yr}$ links lithophile elements concentrations to mineral dust transport by katabatic winds, whilst d-excess and marine element concentrations are tentatively related to incursion of marine cyclones.

The MES stable isotope record suggests that the Ross Sea region experienced $1.6 \pm 1.4{ }^{\circ} \mathrm{C}$ cooler average temperatures during the LIA in comparison to the last $150 \mathrm{yr}$. For every 50-yr interval between 1500 and $1800 \mathrm{AD}$, we observed statistically higher median values of lithophile element concentrations than during the past $150 \mathrm{yr}$. This indicates that strong $\left(>57 \mathrm{~m} \mathrm{~s}^{-1}\right)$ katabatic winds were prevalent during this time. By considering the variable temporal trends exhibited by three groups of lithophile elements, several time periods of especially strong katabatic winds are identifiable by the occurrence of $\mathrm{Al}$ and $\mathrm{Ti}$ concentration increases of over an order of magnitude. These strong wind events occur coincidently with cooler temperatures, as indicated by $\delta \mathrm{D}$ values, during time intervals centered at ca. $1690 \mathrm{AD}, 1770 \mathrm{AD}$ and 1840 AD.

The ice core $\mathrm{MS}^{-}$record and diatom blooms recorded in sediment cores (Leventer and Dunbar, 1988) indicate that marine primary productivity in the Ross Sea polynya was increased between 1600 and $1875 \mathrm{AD}$. We conclude that during the LIA colder temperatures promoted stronger katabatic winds across the Ross Ice Shelf, causing sea ice divergence and creating a greater polynya area in the Ross Sea.

\section{Supplementary material related to this article is available online at: http://www.clim-past.net/8/1223/ 2012/cp-8-1223-2012-supplement.pdf.}

Acknowledgements. We sincerely thank Antarctica New Zealand, the US Polar Program, and Scott Base and McMurdo Station staff for logistical support. We thank the Alfred Wegener Institute for lending us the AWI ice core drill. Recovery of this ice core was made possible by Alex Pyne, Webster Drilling, Glenn and Tony Kingan, Ken Borek Ltd. and Helicopters New Zealand. Ground penetrating radar surveys were conducted by Matt Watson, ScanTec Ltd. Thanks to the staff of the Stable Isotope Laboratory, GNS Science, for their dedication to this work. Figure 7 was produced using a Matlab function available in the "MATLAB Library for Robust Analysis" from the Katholieke Universiteit Leuven and the University of Antwerp (http://wis.kuleuven.be/stat/robust/ Libra.html). This project is funded through the Marsden Fund (VUW0509) and the New Zealand Ministry for Science and Innovation via contracts awarded to Victoria University of Wellington and GNS Science (VICX0704 and CO5X0202).

MES ice core data can be accessed at the iceREADER database http://icereader.org/icereader/.

Edited by: M.-F. Loutre

\section{References}

Ammann, C. M., Joos, F., Schimel, D. S., Otto-Bliesner, B. L., and Tomas, R. A.: Solar influence on climate during the past millennium: Results from transient simulations with the NCAR Climate System Model, P. Natl. Acad. Sci., 104, 3713-3718, 2007.

Arrigo, K. R. and van Dijken, G. L.: Phytoplankton dynamics within 37 Antarctic coastal polynya systems, J. Geophys. Res., 108, 3271,, doi:10.1029/2002JC001739, 2003.

Arrigo, K. R. and van Dijken, G. L.: Annual changes in sea-ice, chlorophyll $a$ and primary production in the Ross Sea, Antarctica, Deep-Sea Res. Pt. II, 51, 117-138, 2004.

Ayling, B. F. and McGowan, H. A.: Niveo-eolian sediment deposits in coastal South Victoria Land, Antarctica: indicators of regional variability in weather and climate, Arct. Antarct. Alp. Res., 38, 313-324, 2006.

Bagnold, R. A.: The physics of blown sand and desert dunes, Methuen, New York, 265 pp., 1941. 
Bertler, N. A. N., Barrett, P. J., Mayewski, P. A., Fogt, R. L., Kreutz, K. J., and Shulmeister, J.: El Niño suppresses Antarctic warming, Geophys. Res. Lett., 31, L15207, doi:10.1029/2004GL020749, 2004a.

Bertler, N. A. N., Mayewski, P. A., Barrett, P. J., Sneed, S. B., Handley, M. J., and Kreutz, K. J.: Monsoonal circulation of the McMurdo Dry Valleys, Ross Sea Region, Antarctica: signal from the snow chemistry, Ann. Glaciol., 39, 139-145, 2004b.

Bertler, N. A. N., Mayewski, P. A., and Carter, L.: Cold conditions in Antarctica during the Little Ice Age - implications for abrupt climate change mechanisms, Earth Planet. Sc. Lett., 308, 41-51, 2011.

Broecker, W. S.: Was a change in thermohaline circulation responsible for the Little Ice Age?, P. Natl. Acad. Sci., 97, 1339-1342, 2000.

Bromwich, D. H., Carrasco, J. F., and Stearns, C. R.: Satellite observations of katabatic-wind propagation for great distances across the Ross Ice Shelf, Mon. Weather Rev., 120, 1940-1949, 1992.

Bull, J. R.: Stable isotope, major and trace element chemistry of modern snow from Evans Piedmont Glacier, Antarctica: insights into potential source regions and relationship of glaciochemistry to atmospheric circulation and vigour, Master of Science thesis, http://hdl.handle.net/10063/1124, School of Geography, Environment and Earth Sciences, Victoria University of Wellington, Wellington, 2009.

Craig, H.: Isotopic variations in meteoric waters, Science, 133, 1702-1703, 1961.

Crowley, T. J.: Causes of climate change over the past 1000 years, Science, 289, 270-277, 2000.

Cuffey, K. M. and Steig, E. J.: Isotopic diffusion in polar firn: implications for interpretation of seasonal climate parameters in icecore records, with emphasis on central Greenland, J. Glaciol., 44, 272-284, 1998.

Dansgaard, W.: Stable isotopes in precipitation, Tellus, 16, 436468, 1964.

Dansgaard, W. and Johnsen, S. J.: A flow model and a time scale for the ice core from Camp Century, Greenland, J. Glaciol., 8, 215-223, 1969.

Denton, G. H. and Broecker, W. S.: Wobbly ocean conveyor circulation during the Holocene?, Quaternary Sci. Rev., 27, 1939-1950, 2008.

Domack, E. W. and Mayewski, P. A.: Bi-polar ocean linkages: evidence from late-Holocene Antarctic marine and Greenland icecore records, Holocene, 9, 247-251, 1999.

Dunbar, G. B., Bertler, N. A. N., and McKay, R. M.: Sediment flux through the McMurdo Ice Shelf in Windless Bight, Antarctica, Global Planet. Change, 69, 87-93, 2009.

Fogt, R. L. and Bromwich, D. H.: Decadal variability of the ENSO teleconnection to the high-latitude South Pacific governed by coupling with the Southern Annular Mode, J. Climate, 19, 979998, 2006.

Grove, J. M.: The Little Ice Age, Methuen, London, 1988.

Herron, M. M. and Langway, C. C.: Firn densification: An empirical model, J. Glaciol., 25, 373-385, 1980.

Hinkley, T. K., Le Cloarec, M. F., and Lambert, G.: Fractionation of families of major, minor, and trace metals across the melt-vapor interface in volcanic exhalations, Geochim. Cosmochim. Acta, 58, 3255-3263, 1994.
Hur, S. D., Cunde, X., Hong, S., Barbante, C., Gabrielli, P., Lee, K., Boutron, C. F., and Ming, Y.: Seasonal patterns of heavy metal deposition to the snow on Lambert Glacier basin, East Antarctica, Atmos. Environ., 41, 8567-8578, 2007.

Jacobs, S. S. and Giulivi, C. F.: Interannual ocean and sea ice variability in the Ross Sea, in: Antarctic Research Series, edited by: Jacobs, S. S. and Weiss, R., AGU, Washington, D.C., 135-150, 1998.

Jochum, K. P., Nohl, U., Herwig, K., Lammel, E., Stoll, B., and Hofmann, A. W.: GeoReM: a new geochemical database for reference materials and isotopic standards, Geostand. Geoanal. Res., 29, 333-338, 2005.

Johnsen, S. J.: Stable isotope homogenisation of polar firn and ice, International symposium on isotopes and impurities in snow and ice, General Assembly XVI, Washington, D.C., 210-219, 1977.

Johnsen, S. J., Clausen, H. B., Cuffey, K. M., Hoffmann, G., Schwander, J., and Creyts, T.: Diffusion of stable isotopes in polar firn and ice : the isotope effect in firn diffusion, Phys. Ice Core Rec., 121-140, 2000.

Jones, P. D. and Mann, M. E.: Climate over past millennia, J. Climate, 42, RG2002, doi:10.1029/2003RG000143, 2004.

Jones, P. D., Briffa, K. R., Osborn, T. J., Lough, J. M., van Ommen, T. D., Vinther, B. M., Luterbacher, J., Wahl, E. R., Zwiers, F. W., Mann, M. E., Schmidt, G. A., Ammann, C. M., Buckley, B. M., Cobb, K. M., Esper, J., Goosse, H., Graham, N., Jansen, E., Kiefer, T., Kull, C., Küttel, M., Mosley-Thompson, E., Overpeck, J. T., Riedwyl, N., Schulz, M., Tudhope, A. W., Villalba, R., Wanner, H., Wolff, E., and Xoplaki, E.: High-resolution palaeoclimatology of the last millennium: a review of current status and future prospects, Holocene, 19, 3-49, 2009.

Jouzel, J. and Merlivat, L.: Deuterium and oxygen 18 in precipitation: Modeling of the isotopic effects during snow formation, J. Geophys. Res., 89, 11749-711757, 1984.

Kalnay, E., Kanamitsu, M., Kistler, R., Collins, W., Deaven, D., Gandin, L., Iredell, M., Saha, S., White, G., Woollen, J., Zhu, Y., Leetmaa, A., Reynolds, R., Chelliah, M., Ebisuzaki, W., Higgins, W., Janowiak, J., Mo, K. C., Ropelewski, C., Wang, J., Jenne, R., and Joseph, D.: The NCEP/NCAR reanalysis 40-year project, B. Am. Meteorol. Soc., 77, 437-471, 1996.

Kaspari, S., Mayewski, P., Kang, S., Sneed, S., Hou, S., Hooke, R., Kreutz, K., Introne, D., Handley, M., Maasch, K., Qin, D., and Ren, J.: Reduction in northward incursions of the South Asian monsoon since 1400 AD inferred from a Mt. Everest ice core, Geophys. Res. Lett., 34, L16701, doi:10.1029/2007GL030440, 2007.

Kellerhals, T., Tobler, L., Brütsch, S., Sigl, M., Wacker, L., Gäggeler, H. W., and Schwikowski, M.: Thallium as a tracer for preindustrial volcanic eruptions in an ice core record from Illimani, Bolivia, Environ. Sci. Technol., 44, 888-893, 2010.

Kreutz, K. J., Mayewski, P. A., Meeker, L. D., Twickler, M. S., Whitlow, S. I., and Pittalwala, I. I.: Bipolar changes in atmospheric circulation during the Little Ice Age, Science, 277, 12941296, 1997.

Kreutz, K. J., Mayewski, P. A., Pittalwala, I. I., Meeker, L. D., Twickler, M. S., and Whitlow, S. I.: Sea level pressure variability in the Amundsen Sea region inferred from a West Antarctic glaciochemical record, J. Geophys. Res., 105, 4047-4059, 2000.

Legrand, M. R. and Mayewski, P. A.: Glaciochemistry of polar ice cores: a review, Rev. Geophys., 35, 219-243, 1997. 
Leventer, A. and Dunbar, R. B.: Recent diatom record of McMurdo Sound, Antarctica: Implications for history of sea ice extent, Paleoceanography, 3, 259-274, 1988.

Markle, B. R., Bertler, N. A. N., Sinclair, K. E., and Sneed, S. B.: Synoptic variability in the Ross Sea region, Antarctic, as seen from back-trajectory modeling and ice core analysis, J. Geophys. Res., 117, D02113, doi:10.1029/2011JD016437, 2012.

Masson, V., Vimeux, F., Jouzel, J., Morgan, V., Delmotte, M., Ciais, P., Hammer, C., Johnsen, S. J., Lipenkov, V. Y., MosleyThompson, E., Petit, J. R., Steig, E. J., Stievenard, M., and Vaikmae, R.: Holocene climate variability in Antarctica based on 11 ice-core isotopic records, Quaternary Res., 54, 348-358, 2000.

Masson-Delmotte, V., Hou, S., Ekaykin, A., Jouzel, J., Aristarain, A., Bernardo, R. T., Bromwich, D., Cattani, O., Delmotte, M., Falourd, S., Frezzotti, M., Gallée, H., Genoni, L., Isaksson, E., Landais, A., Helsen, M. M., Hoffmann, G., Lopez, J., Morgan, V., Motoyama, H., Noone, D., Oerter, H., Petit, J. R., Royer, A., Uemura, R., Schmidt, G. A., Schlosser, E., Simões, J. C., Steig, E. J., Stenni, B., Stievenard, M., van den Broeke, M. R., van de Wal, R. S. W., van de Berg, W. J., Vimeux, F., and White, J. W. C.: A review of Antarctic surface snow isotopic composition: observations, atmospheric circulation, and isotopic modeling, J. Climate, 21, 3359-3387, doi:10.1175/2007jcli2139.1, 2008.

Mayewski, P. A., Meredith, M. P., Summerhayes, C. P., Turner, J., Worby, A., Barrett, P. J., Casassa, G., Bertler, N. A. N., Bracegirdle, T., Naveira-Garabato, A. C., Bromwich, D., Campbell, H., Hamilton, G. H., Lyons, W. B., Maasch, K. A., Aoki, S., Xiao, C., and van Ommen, T.: State of the Antarctic and Southern Ocean climate system, Rev. Geophys., 47, 1-38, 2009.

McMorrow, A., Curran, M. A. J., van Ommen, T. D., Morgan, V., and Allison, I.: Features of meteorological events preserved in a high-resolution Law Dome (East Antarctica) snow pit, Ann. Glaciol., 35, 463-470, 2002.

Merlivat, L. and Jouzel, J.: Global climatic interpretation of the deuterium-oxygen 18 relationship for precipitation, J. Geophys. Res., 84, 5029-5033, 1979.

Michalski, G., Bockheim, J. G., Kendall, C., and Thiemens, M.: Isotopic composition of Antarctic Dry Valley nitrate: implications for $\mathrm{NO}_{\mathrm{y}}$ sources and cycling in Antarctica, Geophys. Res. Lett., 32, L13817, doi:10.1029/2004g1022121, 2005.

Miller, G. H., Geirsdóttir, Á., Zhong, Y., Larsen, D. J., OttoBliesner, B. L., Holland, M. M., Bailey, D. A., Refsnider, K. A., Lehman, S. J., Southon, J. R., Anderson, C., Bjornsson, H., and Thordarson, T.: Abrupt onset of the Little Ice Age triggered by volcanism and sustained by sea-ice/ocean feedbacks, Geophys. Res. Lett., 39, L02708, doi:10.1029/2011g1050168, 2012.

Morales Maqueda, M. M. A., Willmott, A. J., and Biggs, N. R. T.: Polynya dynamics: a review of observations and modeling, Rev. Geophys., 42, RG1004, doi:10.1029/2002RG000116, 2004.

Morgan, V. and van Ommen, T. D.: Seasonality in late-Holocene climate from ice-core records, Holocene, 7, 351-354, 1997.

Morgenstern, U. and Taylor, C. B.: Ultra low-level tritium measurement using electrolytic enrichment and LSC, Isotop. Environ. Health Stud., 45, 96-117, 2009.

Mosley-Thompson, E. and Thompson, L. G.: Little Ice Age (neoglacial) paleoenvironmental conditions at Siple Station, Antarctica, Ann. Glaciol., 14, 199-204, 1990.
Mosley-Thompson, E.: Paleoenvironmental conditions in Antarctica since A.D. 1500: ice core evidence, in: Climate Since A.D. 1500, edited by: Bradley, R. S. and Jones, P. D., Routledge, 572-591, 1995.

Orsi, A. J., Cornuelle, B. D., and Severinghaus, J. P.: Little Ice Age cold interval in West Antarctica: Evidence from borehole temperature at the West Antarctic Ice Sheet (WAIS) Divide, Geophys. Res. Lett., 39, L09710, doi:10.1029/2012g1051260, 2012.

Osterberg, E. C., Handley, M. J., Sneed, S. B., Mayewski, P. A., and Kreutz, K. J.: Continuous ice core melter system with discrete sampling for major ion, trace element, and stable isotope analyses, Environ. Sci. Technol., 40, 3355-3361, 2006.

Parish, T.: Surface winds over the Antarctic continent: A review, Rev. Geophys., 26, 169-180, 1988.

Petit, J. R., Briat, M., and Royer, A.: Ice age aerosol content from East Antarctic ice core samples and past wind strength, Nature, 293, 391-394, 1981.

Petit, J. R., White, J., Young, N. W., Jouzel, J., and Korotkevitch, Y. S.: Deuterium excess in Antarctic snow, J. Geophys. Res., 96, 5113-5122, 1991.

Planchon, F. A. M., Boutron, C. F., Barbante, C., Cozzi, G., Gaspari, V., Wolff, E. W., Ferrari, C. P., and Cescon, P.: Changes in heavy metals in Antarctic snow from Coats Land since the mid-19th to the late-20th century, Earth Planet. Sc. Lett., 200, 207-222, 2002.

Pye, K.: Aeolian dust and dust deposits, Academic Press, London, 1987.

Rankin, A. M., Wolff, E. W., and Mulvaney, R.: A reinterpretation of sea-salt records in Greenland and Antarctic ice cores?, Ann. Glaciol., 39, 276-282, 2004.

Rhodes, R. H., Bertler, N. A. N., Baker, J. A., Sneed, S. B., Oerter, H., and Arrigo, K. R.: Sea ice variability and primary productivity in the Ross Sea, Antarctica, from methylsulphonate snow record, Geophys. Res. Lett., 36, L10704, doi:10710.11029/12009GL037311, 2009.

Rhodes, R. H., Baker, J. A. B., Millet, M.-A., and Bertler, N. A. N.: Experimental investigation of the effects of mineral dust on the reproducibility and accuracy of ice core trace element analysis, Chem. Geol., 286, 207-221, 2011.

Rousseeuw, P. J.: Least median of squares regression, J. Am. Stat. Assoc., 79, 871-881, 1984.

Schulz, M., Balkanski, Y., Guelle, W., and Dulac, F.: Role of aerosol size distribution and source location in a three-dimensional simulation of a Saharan dust episode tested against satellite derived optical thickness, J. Geophys. Res., 103, 10579-10592, 1998.

Sinclair, K. E., Bertler, N. A. N., and Trompetter, W. J.: Synoptic controls on precipitation pathways and snow delivery to highaccumulation ice core sites in the Ross Sea region, Antarctica, J. Geophys. Res., 115, D22112, doi:10.1029/2010jd014383, 2010.

Steig, E. J., Brook, E. J., White, J. W. C., Sucher, C. M., Bender, M. L., Lehman, S. J., Morse, D. L., Waddington, E. D., and Clow, G. D.: Synchronous climate changes in Antarctica and the North Atlantic, Science, 282, 92-95, 1998.

Stenni, B., Proposito, M., Gragnani, R., Flora, O., Jouzel, J., Falourd, S., and Frezzotti, M.: Eight centuries of volcanic signal and climate change at Talos Dome (East Antarctica), J. Geophys. Res., 107, 4076, doi:10.1029/2000jd000317, 2002.

Sturm, P. and Knohl, A.: Water vapor $\delta^{2} \mathrm{H}$ and $\delta^{18} \mathrm{O}$ measurements using off-axis integrated cavity output spectroscopy, Atmos. Meas. Tech., 3, 67-77, doi:10.5194/amt-3-67-2010, 2010. 
Tamura, T., Ohshima, K. I., and Nihashi, S.: Mapping of sea ice production for Antarctic coastal polynyas, Geophys. Res. Lett., 35, L07606, doi:10.1029/2007GL032903, 2008.

Traufetter, F., Oerter, H., Fischer, H., Weller, R., and Miller, H.: Spatio-temporal variability in volcanic sulphate deposition over the past $2 \mathrm{kyr}$ in snow pits and firn cores from Amundsenisen, Antarctica, J. Glaciol., 50, 137-146, 2004.
Vallelonga, P., Candelone, J. P., Van de Velde, K., Curran, M. A. J., Morgan, V. I., and Rosman, K. J. R.: Lead, Ba and Bi in Antarctic Law Dome ice corresponding to the 1815 AD Tambora eruption: an assessment of emission sources using $\mathrm{Pb}$ isotopes, Earth Planet. Sc. Lett., 211, 329-341, 2003.

Zreda-Gostynska, G., Kyle, P. R., Finnegan, D., and Prestbo, K. M.: Volcanic gas emissions from Mount Erebus and their impact on the Antarctic environment, J. Geophys. Res., 102, 15039-15055, 1997. 